\title{
Monolith Metal-Oxide-Supported Catalysts: Sorbent for Environmental Application
}

\author{
Kiman Silas ${ }^{1,2} \mathbb{1}$, Wan Azlina Wan Ab Karim Ghani ${ }^{1,2,3, *}$, Thomas Shean Yaw Choong ${ }^{1}$ \\ and Umer Rashid $4, *$ (D) \\ 1 Department of Chemical and Environmental Engineering, Faculty of Engineering, Universiti Putra Malaysia, \\ UPM Serdang, Selangor 43400, Malaysia; silaskiman@gmail.com (K.S.); csthomas@upm.edu.my (T.S.Y.C.) \\ 2 Sustainable Process Engineering Research Center (SPERC), Faculty of Engineering, \\ Universiti Putra Malaysia, UPM Serdang, Selangor 43400, Malaysia \\ 3 Institute of Plantations Studies, Universiti Putra Malaysia, UPM Serdang, Selangor 43400, Malaysia \\ 4 Institute of Advanced Technology, Universiti Putra Malaysia, UPM Serdang, Selangor 43400, Malaysia \\ * Correspondence: wanazlina@upm.edu.my (W.A.W.A.K.G.); umer.rashid@upm.edu.my or \\ umer.rashid@yahoo.com (U.R.); Tel.: +603-97697393 (U.R.)
}

Received: 22 July 2020; Accepted: 8 August 2020; Published: 4 September 2020

\begin{abstract}
The emission of untreated environmental harmful gases such as sulfur and nitrogen oxide (SOx and NOx) emissions is considered old fashioned, since industries are compelled by governments and legislations to meet the minimum threshold before emitting such substances into the atmosphere. Numerous research has been done and is ongoing to come up with both cost-effective equipment and regenerable catalysts that are adsorbent—or with enhanced sorption capacity—and with safer disposal methods. This work presents the general idea of a monolith/catalyst for environmental application and the technicality for improving the surface area for fast and efficient adsorption-desorption reactions. The chemical reactions, adsorption kinetics, and other properties, including deactivation, regeneration, and the disposal of a catalyst in view of environmental application, are extensively discussed.
\end{abstract}

Keywords: pollutants; monolith; catalyst; kinetics; regeneration; adsorption

\section{Introduction}

Atmospheric pollutants include acid gases such as carbon dioxide $\left(\mathrm{CO}_{2}\right)$, sulfur oxides (SOx), nitrogen oxides (NOx), volatile organic compounds (VOCs), heavy metals, fly ash, and particulate matter [1-3]. The emitted pollutants are as a result of industrial activities from coating industries, fluid catalytic cracking units (FCCU), circulating fluidized bed combustors (CFBC), combustion behaviors of incinerators, coal fuel, automotives, plastic, and power plants which give rise to deleterious health and environmental effects [4-9]. For example, the world consumption of about 5-6 billion metric tons of coal is reported annually, and by 2040, it is expected to reach 12,500 Mt [10]. Coal is the dominant fossil fuel currently in use that accounted for $38 \%$ of electricity generated in 2000, $17.5 \%$ hydropower, $17.3 \%$ natural gas, $16.8 \%$ nuclear, $9 \%$ oil, and $1.6 \%$ non-hydropower, yet coal is expected to remain the dominant fuel for power generation by 2020 [11].

Adsorption is a simple and cheap method for extracting process gases and vapors from the atmosphere, and the adsorption of contaminants by regenerable catalysts is becoming common in reducing the menace of air pollution [12]. Recently, the multipollutant simultaneous removal techniques used to include carbon-based material adsorption and nonthermal plasma (NTP) technologies [13]. In addition, attention has been paid to the chemical reaction of acid gases with a metal oxide (chemical adsorbent) or the actual sorption of solids (atomic adsorbent) [14]. The solid adsorbents commonly used in controlling flue gas pollutants are the non-regenerative $(\mathrm{CaO}$ and $\mathrm{MgO})$ and regenerative 
(zeolites, silica gel, charcoal, etc.) adsorbents [15]. The final disposal of the exhausted catalyst is a paramount topic of research. Commonly, a layer of sealant, such as bitumen, polyethylene or concrete, is used to encapsulate catalyst residues that may cause environmental problems [16]. In terms of economy, the regeneration of the exhausted catalyst is preferred over the adsorbent replacement [17].

Numerous research has been done and is ongoing to come up with cost-effective equipment and regenerable catalysts that are adsorbent-or with enhanced sorption capacity-and with safer disposal methods. For example, some literatures [18-24], worked on the development of catalysts but have not considered the regeneration aspects. Other work has reported the regenerations of catalysts $[3,25-28]$ but failed to give good performance after few regeneration cycles due to poor understanding of the catalyst development. Besides, most of the studies does not give attention to the acid gases as the adsorbates, meanwhile activated carbon (AC) is mostly used as the catalyst support [29-32]. However, Kiman et al. [33] recommended the support of metal oxides catalysts with monolith due to issues with $\mathrm{AC}$, such as low adsorptivity, plugging, and difficulty in mass transport processes, which can be overcome with the monolith adsorbent. Therefore, there is a growing need for the review of studies of catalysts with support and regeneration for environmental protection and cost effectiveness.

This study reviewed the potential of monolith as a metal oxide catalyst support. Furthermore, the industrial application specifically in the SOx/NOx abatement from flue gas and the background of laboratory adsorptive equipment, basic chemistry of catalysis, application, and regeneration are discussed.

\section{Monolith Structure}

Monolith could be a metal, plastic, or ceramic structure with continuous unitary open structures without bends that hardly obstructs flow; it has parallel channels that extrude in various geometry (circular, square, rectangle, hexagonal etc.) [34-37]. A vehicle monolithic exhaust converter is reported to have the diameter of $D+0.1 \mathrm{~m}$, while the monolith sections for treating flue gas of power plants has a large-diameter of $D^{\prime} 2 \mathrm{~m}$ [36]. The structure is defined by width, wall thickness, void fraction (varies between 0.5 and 0.9 and is commonly expressed as the open front region, OFA), channel openings (dh), and cell density (ranges between 100 and 1200 channels per square inch cpsi) [38,39]. Silas et al. [3] gave the specification of a bare monolith (cordierite) they used in their study of flue gas cleaning as follow in Table 1:

Table 1. Specification of bare monolith.

\begin{tabular}{ccc}
\hline Monolith & Cells & Chemical Compositions \\
\hline Cross section circular & Channel square & $\mathrm{SiO}_{2} 50.9 \pm 1.0 \%$ \\
Surface area $1 \mathrm{~cm}^{2} / \mathrm{g}$ & Wall thickness $0.25 \pm 0.02 \mathrm{~mm}$ & $\mathrm{Al}_{2} \mathrm{O}_{3} 35.2 \pm 1.0 \%$ \\
Length $2.50 \pm 0.02 \mathrm{~mm}$ & Width $1.02 \pm 0.02 \mathrm{~mm}$ & $\mathrm{MgO}^{2} 13.9 \pm 0.5 \%$ \\
Diameter $2.50 \pm 0.02 \mathrm{~mm}$ & Cells $400(\mathrm{cpsi})$ & Others $<1 \%$ \\
\hline
\end{tabular}

Cordierite can be used as a catalyst support; however, it has a low specific surface area and weak catalyst-support interaction [40]. The specific surface area of cordierite is less than $1 \mathrm{~m}^{2} \mathrm{~g}^{-1}$, meanwhile coating can increase the specific surface area (to about $15-30 \mathrm{~m}^{2} \mathrm{~g}^{-1}$ ) and improve the dispersion of active components. Moreover, acidic treatment increases the surface area up to $200 \mathrm{~m}^{2} \mathrm{~g}^{-1}[35,40,41]$. Washcoat (provides high surface area), substrate (gives the shape and mechanical properties), and active phase (the catalytic element) are considered as the three components of modified structured catalysts [42,43]. Lei et al. [41] found that metal oxide may be used as the active phase, $\gamma-\mathrm{Al}_{2} \mathrm{O}_{3}$ as the washcoat and cordierite as support in the application where dust and carbon are avoided while handling a large volume of flue gases. The impregnation and calcinations of catalyst/support are significant processes in the catalyst development.

The term calcination is referred to the heat-treatment beyond drying and without the formation of a liquid phase, it can be carried out in different atmospheres $\left(\mathrm{N}_{2}\right.$, vacuum, etc.) and at temperatures 
higher than those used in the catalytic reaction or catalyst regeneration [43]. The process converts the impregnated metal precursor (i.e., $\mathrm{Cu}\left(\mathrm{NO}_{3}\right)_{2} \cdot 3 \mathrm{H}_{2} \mathrm{O}$ to $\mathrm{CuO}$ ) to the formation of finished metal oxide catalysts [14]. At a high calcination temperature, the activity of the catalyst will be low because some redundant oxides occupy the active sites and its dispersion on the support [44]. Figure 1 is the structure of the monolith.
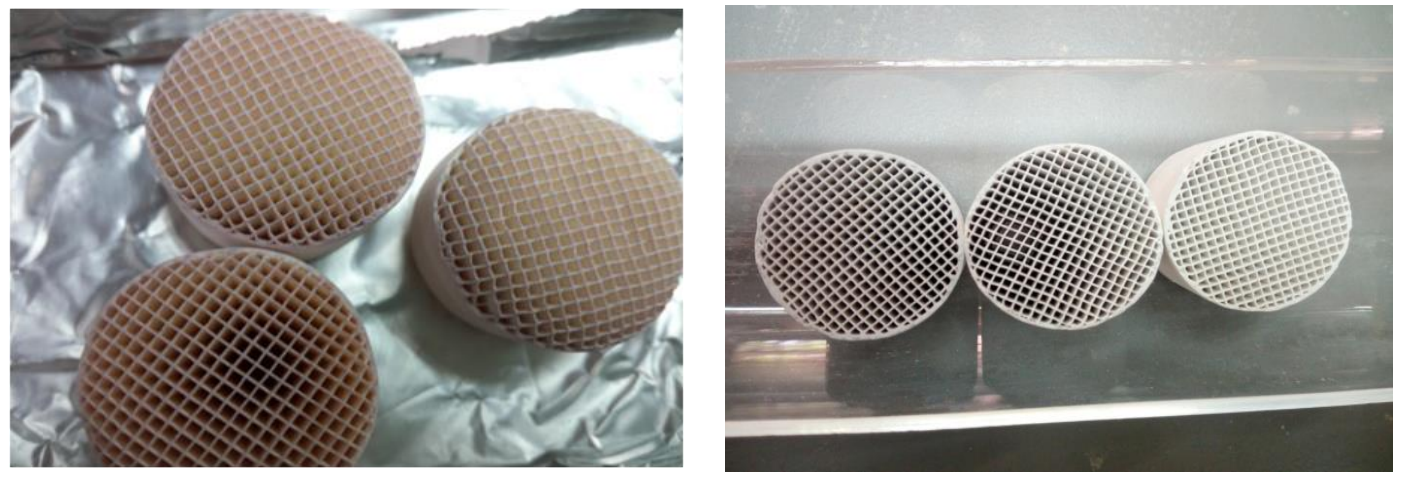

Figure 1. Monolith structure.

Recent studies have focused on the use of monolithic adsorbents as catalyst support. Table 2 depicts the recent monoliths used in the literature.

Table 2. The recent application of monoliths as catalysts.

\begin{tabular}{|c|c|c|c|c|}
\hline Adsorbent/s & $\begin{array}{l}\text { Catalyst/s } \\
\text { Supported }\end{array}$ & Method of Doping & Application & Ref. \\
\hline Monolith & $\mathrm{Co}_{3} \mathrm{O}_{4}$ & $\begin{array}{c}\text { Pore impregnation, } \\
\text { deposition } \\
\text { precipitation, } \\
\text { hydrothermal methods }\end{array}$ & $\begin{array}{l}\text { Simultaneous } \mathrm{SO}_{2} / \mathrm{NOx} \\
\text { removal from flue gas }\end{array}$ & [3] \\
\hline Monolith & $\mathrm{TiO}_{2}, \mathrm{Fe}_{2} \mathrm{O}_{3}$ & $\begin{array}{l}\text { One-pot self-assembly } \\
\text { method }\end{array}$ & $\begin{array}{c}\text { Low-temperature } \\
\mathrm{SO}_{2} \text {-tolerant monolithic } \\
\text { selective catalytic } \\
\text { reduction } \mathrm{SCR} \text { catalysts } \\
\text { with high } \mathrm{N}_{2} \text { selectivity }\end{array}$ & [45] \\
\hline $\begin{array}{l}\text { Zeolite-based } \\
\text { cordierite } \\
\text { monoliths }\end{array}$ & $\begin{array}{l}\text { Pd-Ce-Zeolite } \\
\text { powder catalyst }\end{array}$ & Impregnation & $\begin{array}{l}\mathrm{NOx} \mathrm{CH}_{4} \text { selective } \\
\text { catalytic reduction }\end{array}$ & [46] \\
\hline Cordierite & $\mathrm{Mn}-\mathrm{Ce} / \mathrm{Al}_{2} \mathrm{O}_{3}$ & $\begin{array}{l}\text { Impregnation, } \\
\text { deposition } \\
\text { precipitation, } \\
\text { modified deposition } \\
\text { precipitation, }\end{array}$ & $\mathrm{SO}_{2}$ and $\mathrm{NO}$ conversion & [47] \\
\hline Cordierite & $\mathrm{MnOx} / \mathrm{TiO}_{2}$ & $\begin{array}{l}\text { Sol-gel-impregnation } \\
\text { method, }\end{array}$ & $\begin{array}{l}\text { Low-temperature selective } \\
\text { catalytic reduction }(\mathrm{SCR}) \\
\text { of } \mathrm{NOx} \text { with } \mathrm{NH}_{3}\end{array}$ & [48] \\
\hline
\end{tabular}

\section{Catalysts}

Industrial catalysts are either heterogeneous (catalysts and reactants in distinct physical phases) or homogeneous (catalysts and reactants in the same phase) [49]. A heterogeneous catalyst is a material that has a relative amount of different components characterized by active species, surface area, physical and/or chemical promoters, size, supports, shape, and pore volume distribution, which give rise to an optimum catalyst with good selectivity, activity, lifetime, ease of regeneration, and low cost [43]. According to Teoh et al. [50], if the adsorption process occurs on a carbon-coated monolith's surface, it is heterogeneous. Most of the industries prefer heterogeneous catalysts because of the advantages they offer, such as potential reusability, economic and environmental friendliness, stability, low toxicity, and ease of recovery from the reaction system [51-58]. 
Approximately $80 \%$ of the chemical products generated are manufactured through heterogeneous catalytic processes and generate global annual sales of around USD 1500 billion [51-59]. Furthermore, catalysis is used in the production of polymers, pharmaceuticals, cosmetics, foods, in new processes for the generation of clean energy and abating environmental pollutants [51]. Meanwhile, the homogeneous catalysts exhibit difficulty to recycle, complicated processes of post treatment, and enormous amounts of waste-water generation [53-55,60]. Supported metal oxides are known for unstable activity in the industrial applications due to $\mathrm{H}_{2} \mathrm{O}$, hydrocarbons, $\mathrm{O}_{2}$, temperature, and acid gases deactivation; therefore, the development of catalytic materials that can be used for eliminating atmospheric pollutants is required $[61,62]$.

\subsection{Metal-Oxide-Supported Catalysts}

Catalysts without support are easier to be deactivated than supported catalysts; therefore, the synthesis and supporting of nanophase metal oxides with small particle size and high surface area may provide the improvements needed for industrial catalysts $[63,64]$, since low metal oxide loading on the support can tremendously enhance the catalyst's performance [65]. Already, the technology of impregnating metal oxides $\left(\mathrm{Mn}_{2}, \mathrm{O}_{3}, \mathrm{NiO}, \mathrm{Co}_{3} \mathrm{O}_{4}, \mathrm{~V}_{2} \mathrm{O}_{5}, \mathrm{CuO}\right.$, etc.) and noble metals ( $\mathrm{Pt}, \mathrm{Pd}$, and $\mathrm{Rh}$ ) on structural adsorbents for application in stationary and automotive pollutants removal is established [14]. It is proven that the catalyst coating on monoliths enhances the structural properties like resistance to thermal shock and convenient separation from media [66].

Figure 2 shows the scanning electron microscopy and energy dispersed X-ray (SEM/EDX) spectra of monolith $\mathrm{Co}_{3} \mathrm{O}_{4}$ supported adsorbents. The energy dispersed X-ray (EDX) spectra showed the presence of $\mathrm{Co}_{3} \mathrm{O}_{4}$ of about $1.1 \%$ in the activated carbon monolith, while the presence of carbon $(41.44 \%)$ is seen from the carbonization process development. The SEM image disclosed abundant pores with dispersed $\mathrm{Co}_{3} \mathrm{O}_{4}$ catalysts.

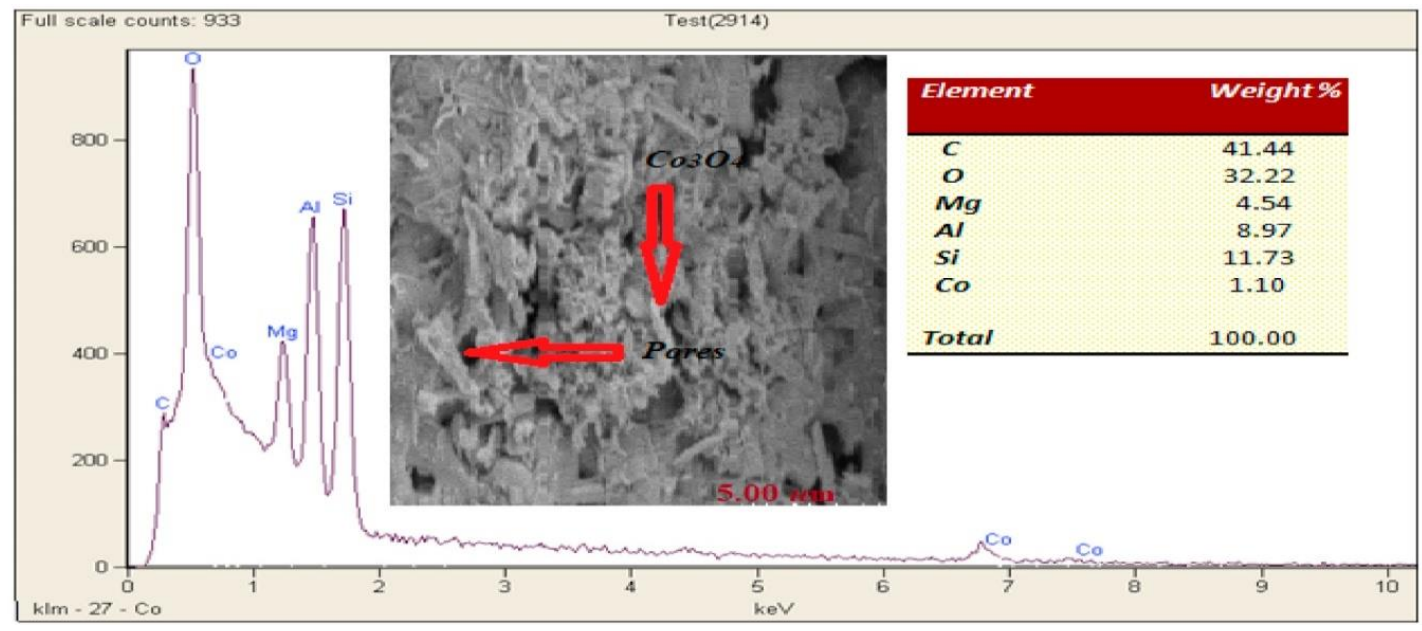

Figure 2. SEM/EDX spectra of monolith $\mathrm{Co}_{3} \mathrm{O}_{4}$ supported adsorbents. Reproduced with permission from Silas et al. [67]. Copyright 2018 Elsevier Ltd. [67].

The catalytic activity and selectivity of a metal oxide is correlated with certain characteristics, such as oxygen non-stoichiometry, composition, surface area, volume, shape, reducibility, and pore structure $[4,68]$. In addition, the key considerations in preparation include the choice of active chemical composition, promotion of catalysts, active phase deposition methods, and oxidative and reductive treatments [4]. Furthermore, the support should have the following properties: high surface area and acidity, pore volume, thermal conductivity, and reactivity [69]. Figure 3 shows the procedure for monolith $/ \mathrm{Co}_{3} \mathrm{O}_{4}$-based catalysts by impregnation of pore volume, precipitation of deposition, and methods of hydrothermal synthesis [70]. 


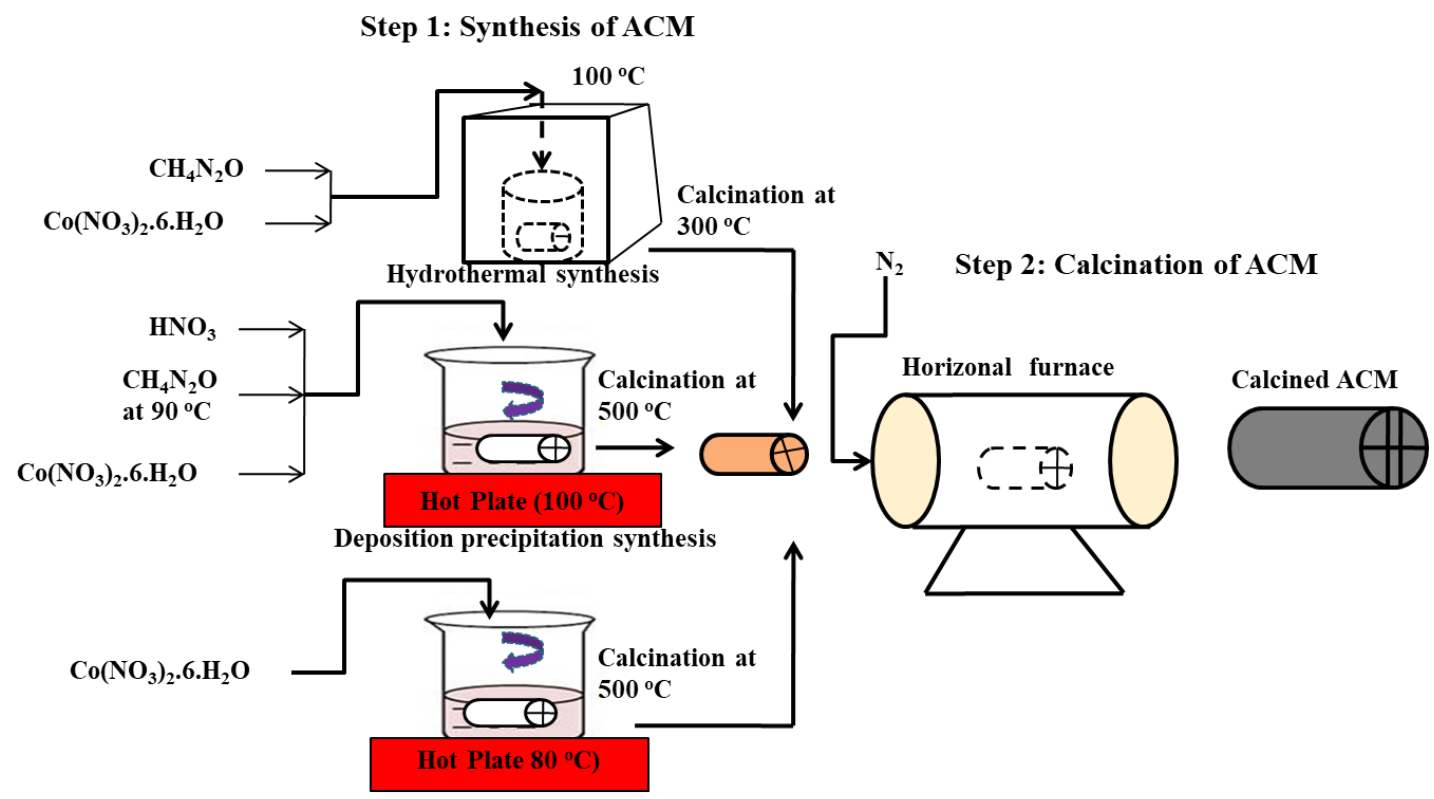

Wet pore impregnation synthesis

Figure 3. Schematic representation of synthesis procedure.

A good approach of developing the adsorbent surface is to manufacture a metal oxide material as an ordered porous structure [68]. An example is a monolithic cordierite-based catalyst $\left(\mathrm{CuO} / \mathrm{Al}_{2} \mathrm{O}_{3}\right)$ developed to remove $\mathrm{SO}_{2}$ and $\mathrm{NO}$ from flue gas at $350-400{ }^{\circ} \mathrm{C}$ simultaneously, but high reaction temperature and energy consumption were reported [44]. Boyano et al. [71] found that for adsorbent/catalyst to be economically competitive then it must perform at a low-temperature range of $100-300{ }^{\circ} \mathrm{C}$.

\subsection{Catalyst Loading}

The good understanding of catalyst loading on the support is imperative because higher loading can result in active site blockage, metal sintering, and/or reduction in catalytic activity, and also, lower loading may lead to fewer active sites with low activity ascribed to incomplete coverage of the internal surface area [72-74]. Table 3 shows former catalyst loading on supports.

Table 3. Reviewed catalyst loading on supports.

\begin{tabular}{|c|c|c|c|c|c|}
\hline Adsorbent & Catalyst & $\begin{array}{l}\text { Catalyst } \\
\text { Loading }\end{array}$ & $\begin{array}{l}\text { Synthesis } \\
\text { Method }\end{array}$ & Application & Ref. \\
\hline $\mathrm{AC}$ & $\begin{array}{c}\mathrm{Fe}\left(\mathrm{NO}_{3}\right)_{3} \cdot 9 \mathrm{H}_{2} \mathrm{O} \\
\mathrm{Mn}\left(\mathrm{NO}_{3}\right)_{2} \\
\mathrm{Co}\left(\mathrm{NO}_{3}\right)_{2} \cdot 6 \mathrm{H}_{2} \mathrm{O} \\
\mathrm{Ce}\left(\mathrm{NO}_{3}\right)_{3} \cdot 6 \mathrm{H}_{2} \mathrm{O} \\
\left(\mathrm{V}, \mathrm{NH}_{4} \mathrm{VO}_{3} \mathrm{H}_{2} \mathrm{C}_{2} \mathrm{O}_{4}\right) \\
\mathrm{Cu}\left(\mathrm{NO}_{3}\right)_{2} \cdot 3 \mathrm{H}_{2} \mathrm{O}\end{array}$ & $\begin{array}{c}1.79 \times 10^{-2} \\
1.82 \times 10^{-2} \\
1.70 \times 10^{-2} \\
7.3 \times 10^{-3} \\
1.96 \times 10^{-2} \\
1.57 \times 10^{-2} \\
\mathrm{Mmol}\end{array}$ & $\begin{array}{l}\text { Pore volume } \\
\text { wetness } \\
\text { impregnation }\end{array}$ & $\begin{array}{l}\text { Oxidation of } \mathrm{H}_{2} \mathrm{~S} \text { to } \\
\text { elemental sulfur. }\end{array}$ & [75] \\
\hline Monolith & $\mathrm{Ni}\left(\mathrm{NO}_{3}\right)_{2}$ & $1 \mathrm{wt} \%$ & $\begin{array}{l}\text { Deposition } \\
\text { precipitation }\end{array}$ & $\begin{array}{l}\text { Comparison of } \\
\text { monolith and a } \\
\text { trickle-bed catalyst } \\
\text { system }\end{array}$ & [76] \\
\hline $\mathrm{AC}$ & $\mathrm{V}_{2} \mathrm{O}_{5}$ & $1 \mathrm{wt} \%$. & $\begin{array}{l}\text { Pore volume } \\
\text { impregnation }\end{array}$ & $\begin{array}{l}\text { Desulfurization and } \\
\text { regeneration }\end{array}$ & [7] \\
\hline Cordierite & $\mathrm{Cu} / \mathrm{Cu}\left(\mathrm{NO}_{3}\right)_{2} \cdot 3 \mathrm{H}_{2} \mathrm{O}$ & $1.5 \%$ & $\begin{array}{c}\text { Incipient } \\
\text { impregnation }\end{array}$ & $\begin{array}{c}\text { Modelling of } \\
\text { monolithic SCR reactor }\end{array}$ & [41] \\
\hline
\end{tabular}


Figure 4 shows the alumina deposition using urea method, which illustrates the deposition precipitation technique. The pores in the monolith support were attached with the mixed metal oxides by the deposition precipitation technique, which acts as catalyst. Furthermore, the calcinations process ensured the consolidation of the support and the catalyst resulting into a unique composite for convenient application.

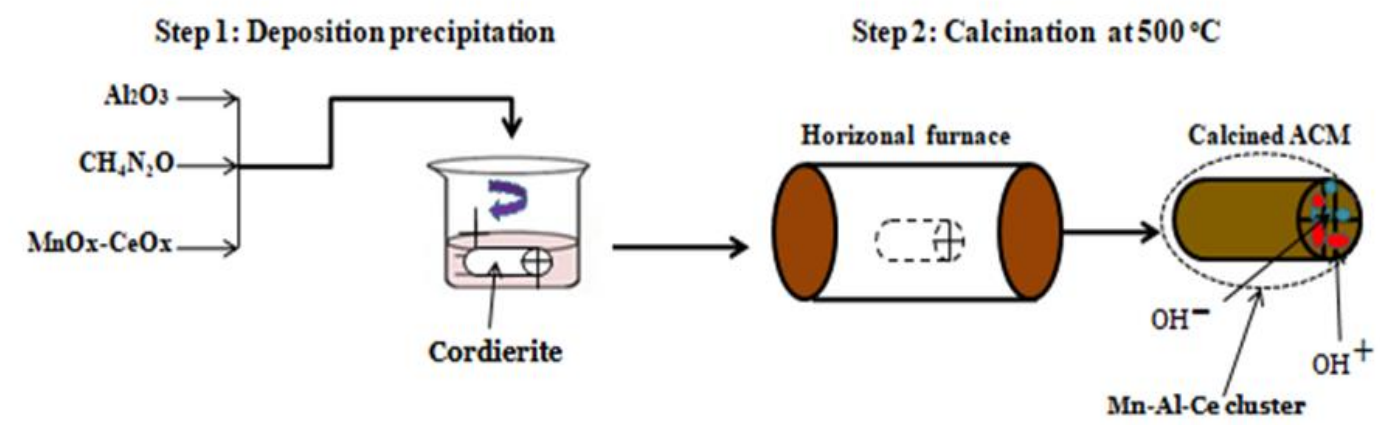

Figure 4. Schematic of the catalyst loading methods.

\subsection{Catalyst Deactivation}

Catalyst loss of activity with time is inevitable, and deactivation may occur in the case of cracking catalysts in seconds but may last for 5-10 years in iron catalyst synthesis or several years in human metabolism $[16,77,78]$. Common reasons for deactivation of the catalyst include: evaporation, carbonaceous deposit formation (coking), poisoning (phosphorous, presence of the $\mathrm{SO}_{2}$ in the flue gas), washout, reduction, accidental temperature rise, corrosion plugging of pores, and metal crystallite encapsulation; whereas, deactivation are classified as: poisoning, coking or fouling, sintering, and phase transformation [51,69,77,79]. Moulijn et al. [80], addresses how deactivation affects the rate of reaction since catalytic activity is proportional to the number of active sites as shown in the following equation:

$$
K_{\mathrm{O}}=N_{\mathrm{T}} K_{\mathrm{i}} \eta
$$

where, $K_{\mathrm{o}}$ and $K_{\mathrm{i}}$ are the observed and intrinsic rate constants for the reactions per active site, $N_{\mathrm{T}}$ is the total number of active sites, and $\eta$ is the effectiveness factor.

Catalyst deactivation can be caused by the decreased in the number of active sites ( $N_{\mathrm{T}}$ decreases), decrease in the quality of the active sites ( $K_{\mathrm{i}}$ decreases), and degradation in accessibility of the pore space ( $\eta$ decreases). Poisoning can cause a decrease in the number of active sites according to the following relation:

$$
N_{\mathrm{T}}=N_{\mathrm{T}}(1-\alpha)
$$

where, $\alpha$ is the fraction of the sites poisoned. The relative loss of activity is given as:

$$
\Delta \mathrm{x}=\frac{(\mathrm{xo}-\mathrm{xt})}{\mathrm{xo}} 100 \%
$$

where, $\Delta x$ is the relative loss of activity, $x$ the conversion, and indices 0 and $t$ stand for times of exposure [81]. The blockage of active sites as a result of poisoning are discussed in detail elsewhere [62,79-83]. Table 4 shows the types, treatment, and causes of catalyst deactivation. 
Table 4. Types and causes of catalyst deactivation.

\begin{tabular}{|c|c|c|c|}
\hline Deactivation Type & Cause of Deactivation & Prevention/Treatment & Ref. \\
\hline Chemical poisoning & $\begin{array}{l}\text { Sulfur, chlorine, heavy } \\
\text { metals, halogens, silicones, } \\
\text { phosphorus, acid catalysts } \\
\text { are poisoned by basic } \\
\text { materials, oxide catalysts are } \\
\text { poisoned by } \mathrm{Pb}, \mathrm{Hg} \text {, As, Cd. }\end{array}$ & $\begin{array}{l}\text { Metal oxide-based catalysts } \\
\text { exhibit good resistant to } \\
\text { deactivation by poisoning, } \\
\text { oxidation can reduce the } \\
\text { effect of some } \\
\text { poisons/regeneration. }\end{array}$ & {$[16,79,83]$} \\
\hline Thermal sintering & $\begin{array}{l}\text { Catalyst exposure to high } \\
\text { temperature, high partial } \\
\text { pressure of water, crystallite } \\
\text { growth on the catalytic } \\
\text { phase resulting in loss of } \\
\text { catalytic surface area, } \\
\text { calcinations process, } \\
\text { reduction (fresh or } \\
\text { passivated catalyst), reaction } \\
\text { (hot spots, maldistribution), } \\
\text { or regeneration. }\end{array}$ & $\begin{array}{l}\text { Stabilizers are used to fill } \\
\text { vacancies in the lattice, } \\
\text { employing chemical vapor } \\
\text { deposition (CVD)-type } \\
\text { treatment to restore the } \\
\text { active sites/it is better to } \\
\text { avoid sintering from } \\
\text { occurring. }\end{array}$ & {$[16,77,80,83]$} \\
\hline Fouling & $\begin{array}{l}\text { Carbon deposit, ash, soot, } \\
\text { rust, and scale }\end{array}$ & Regeneration/rejuvenation & {$[16,80]$} \\
\hline
\end{tabular}

\subsection{Surface Area and Mechanism}

The surface area value is a variable factor depending on how the isothermic adsorption is calculated and perceived. The model process of adsorption mechanisms is formulated for suitable equations, which predicts required parameters, such as surface area whose predicted values are used to validate adsorption equations and general behavior [84]. The porosity of materials is classed based on the basis of vapor adsorption behavior of each pore: [85-89]

1. micropores $(d<2 \mathrm{~nm})$.

2. mesopores $(2 \mathrm{~nm}<d<50 \mathrm{~nm})$.

3. macropores $(50 \mathrm{~nm}<d<200 \mathrm{~nm})$.

Figure 5 shows the positioning of micro, meso, and macropores on a catalyst.

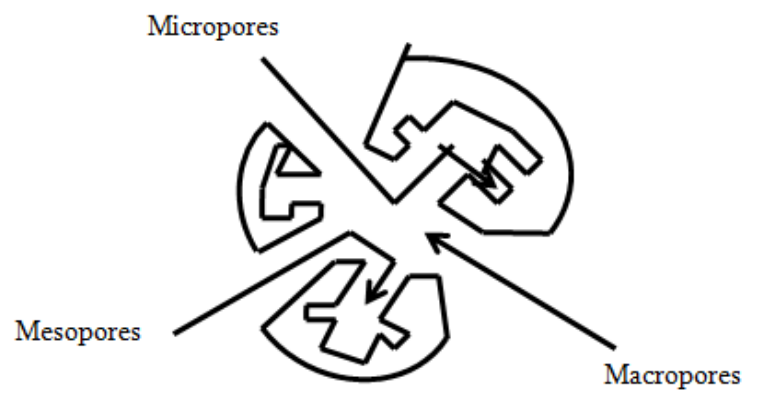

Figure 5. Positions of micro, meso, and macropores on a catalyst active site.

Monoliths are mainly mesoporous [3,85,90-92]. Previously, Hu et al. [93], found that mesopore volumes and surface area lie between the limits $0.1-0.5 \mathrm{~cm} / \mathrm{g}$ and the range of $20-100 \mathrm{~m} / \mathrm{g}$ and serves as the main transport arteries for the adsorbate. Because of their large specific surface area, highly ordered mesoporous structure and interconnected channels, mesoporous materials attract more attention [94]. It should be noticed that meso and macropores act as a passage to the micropores for adsorbing [95].

The high surface area and pore volume in a material are imparted by mesopores and micropores through numerous active sites and size selectivity for molecules, while macropores improve mass transfer in order to overcome diffusion difficulties found in the mesopores and micropores pores [68]. 
Furthermore, over the relative pressure range of about $0.05-0.35$, the BET and Langmuir equations describe the adsorption process, whereas the Dubinin-Astakhov (DA) and Dubinin-Radushkevich (DR) equations interpret adsorption phenomena at much lower relative pressures [84].

Activation is a process of improving the adsorption capabilities of an adsorbent by various processes resulting in pore structure enhancement and a decrease in the weight of the substrate, referred to as burn-off [96]. The work of Lázaro et al. [91] specified that the use of $\mathrm{CO}_{2}$ as an activating agent can increase microporosity, mesoporosity, and macroporosity. The purpose of activation is to enlarge the diameters of the fine pores and create new pores [85]. Moreno-Castilla and Pérez-Cadenas [37] suggested activation with $\mathrm{CO}_{2}$ at $700-900{ }^{\circ} \mathrm{C}$.

One of the most popular methods for studying the mechanism of a reaction is to investigate the influence of electronic factors on the rate of the reaction. Figure 6 shows the $\mathrm{CO}$ oxidation reaction on a CuMnOx catalyst surface.
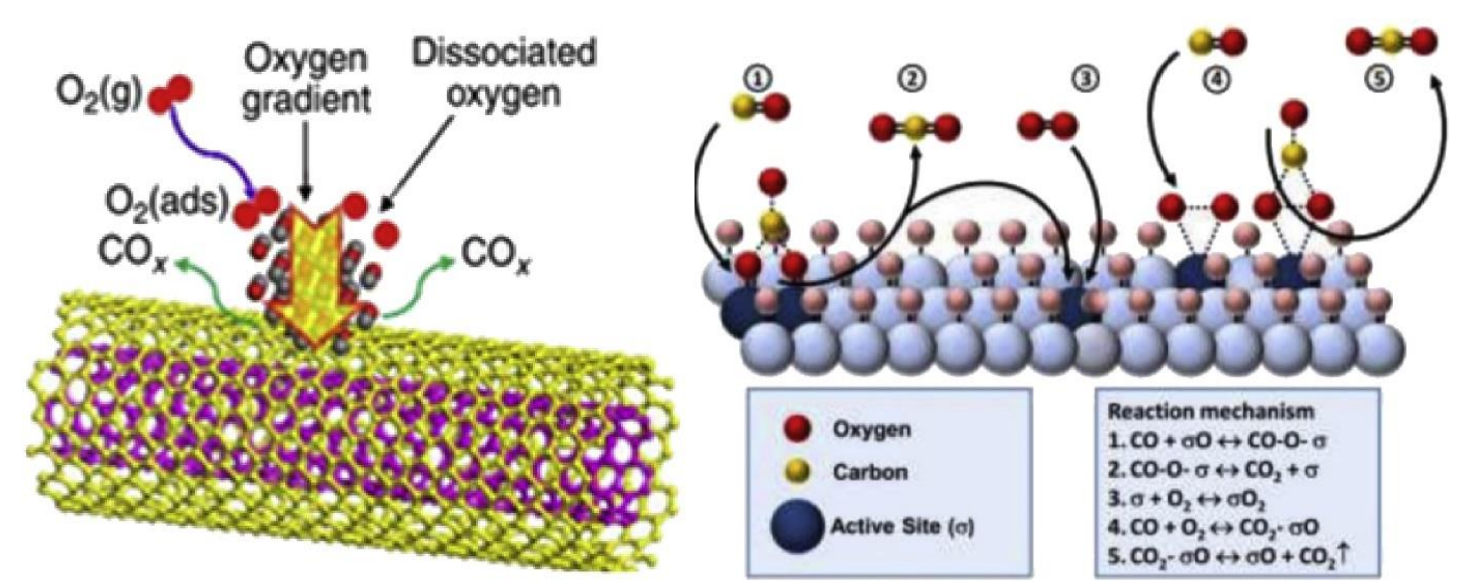

Figure 6. Mechanism of CO oxidation over a CuMnOx catalyst. Reproduced with permission from Dey and Dhal [97]. Copyright 2019 Elsevier Ltd. [97].

The mechanism involves $\mathrm{O}_{2}$ adsorption to form $\mathrm{O}_{2}$ * precursors, which split on a vicinal vacancy, while in the second mechanism, the $\mathrm{O}_{2}$ activation occurs via the kinetically applicable $\mathrm{CO}^{*}$-assisted $\mathrm{O}_{2}$ dissociation step without the specific concern of stable $\mathrm{O}_{2}{ }^{*}$ precursors [97].

\section{Adsorption Kinetics}

Catalysis is based on changes in the kinetics of chemical reactions, while kinetics defines the relative rates of numerous competitive pathways available to reactants, while thermodynamics acts as a gateway to the most stable products [51]. Useful information on the behavior of adsorption could be obtained from thermodynamics parameters, such as entropy (DS), the free energy (DG), and enthalpy change (DH) [98]. Desorption is the reverse adsorption process by which adsorbed molecules removed from the adsorbent with about equal energy released during adsorption are supplied for desorption; such an energy requirement dominates the operating costs for some separations processes [99].

Adsorption refers to the change in the concentration of a substance at the interface compared to the adjacent phases, and the time dependence of adsorption on sorption surfaces is called the kinetics of adsorption $[84,100]$. The enrichment of ions, atoms, and molecules on the surface area of an interface occurs during the adsorption process. Adsorption kinetic studies provide useful information about the mechanism involved in the adsorbent-adsorbent reaction and the time required to complete the adsorption process, which is one of the requirements for choosing solid adsorbents for a particular application [101].

According to Rezaei and Webley [102], the volumetric working capacity, pressure drop, mass transfer, and thermal management governs the adsorbent performance of adsorptive gas separation processes for an adsorption isotherm. The adsorption kinetics is determined by the following steps: [100] 
a. External diffusion; molecules diffuses towards the interface space from the bulk phase.

b. Internal diffusion; molecules diffuses inside the pores.

c. Surface diffusion; molecules diffuses in the surface phase.

d. Adsorption-desorption elementary processes.

Catalyst absorptivity is described by adsorption isotherms, which are characterized by constants that express the surface properties with models such as the Lagergren, Langmuir, and Freundlich used to fit the isotherms $[98,103]$. The important sorbent characteristics, including pore volume, pore size, specific surface area, and energy distribution, are described by the adsorption isotherm equations that deal with the physical adsorption of gases and vapor, whereas the interpretation of specific curves of the adsorption mechanism describes the efficiency of the sorbent in utilitarian processes, purification and separation [100]. The adsorption capacity of the catalyst on the adsorbent surface at the equilibrium state is given as: $[50,104]$

$$
\mathrm{q}_{\mathrm{e}}=\frac{\left(\mathrm{C}_{\mathrm{o}}-\mathrm{C}_{\mathrm{e}}\right) \mathrm{V}}{\mathrm{W}}
$$

where $\mathrm{q}_{\mathrm{e}}$ is the adsorbed amount $(\mathrm{mg} / \mathrm{g}), \mathrm{C}_{\mathrm{o}}$ is the initial concentration $(\mathrm{mg} / \mathrm{L})$ and $\mathrm{C}_{\mathrm{e}}$ is the equilibrium concentration $(\mathrm{mg} / \mathrm{L}) . \mathrm{V}$ is the volume of the solution $(\mathrm{L})$ and $\mathrm{W}$ is the mass of adsorbent used $(\mathrm{mg})$, respectively. The adsorption capacity at predetermined time intervals is calculated by using following equation: $[50,105]$

$$
\mathrm{q}_{\mathrm{e}}=\frac{\left(\mathrm{C}_{\mathrm{o}}-\mathrm{C}_{\mathrm{t}}\right) \mathrm{V}}{\mathrm{w}}
$$

where $C_{t}$ is the adsorbate concentration $(\mathrm{mg} / \mathrm{L})$ at time $\mathrm{t}(\mathrm{s})$. According to Chaudhary and Balomajumder [106], the removal efficiency (RE) can be calculated from:

$$
R E=\frac{\left(C_{o}-C_{t}\right) 100 \%}{C_{o}}
$$

Adsorption occurs in gas-solid systems at the outside and vicinity of solid surface structure while in absorption, so the molecules penetrate the surface layer and enter the bulk solid [107]. To calculate the adsorption capacity of a catalyst, Equation (6) is uniquely used in a liquid-solid interface while for a gas-solid interface the following equation is used:

$$
q=\frac{y \cdot F}{M} \int_{0}^{t b}\left(1-\frac{\mathrm{C}_{\mathrm{t}}}{\mathrm{C}_{\mathrm{o}}}\right) d t
$$

where $C_{t}$ is the effluent concentration, $C_{o}$ is the influent concentration, and $y, M, F$, and $t_{b}$ are the mole fraction in the feed, amount of the catalyst $(\mathrm{g})$, volumetric flow rate $(\mathrm{mL} / \mathrm{min})$, and breakthrough time ( $\mathrm{min}$ ), respectively. Several studies demonstrated the application of Equation (7) in calculating adsorption capacity $[3,92,98,108,109]$. Adsorption capacity can have units of $\mathrm{mg} \mathrm{g}^{-1}$ or $\mathrm{mmol} \mathrm{g}^{-1}$ or $\mathrm{cm}^{3} \mathrm{~g}^{-1}$.

\subsection{The Freundlich Isotherm Model}

The Freundlich isotherm model was the earliest known empirical equation used for nonideal sorption that involves heterogeneous adsorption through a multilayer adsorption mechanism. The following postulations were considered in formulating the Freundlich model: [104]

(a) the adsorption layer is energetically heterogeneous and (b) the density of the adsorbed quantity increases. Freundlich model is defined as: [98]

$$
\mathrm{q}_{\mathrm{e}}=\mathrm{K}_{\mathrm{f}} \mathrm{C}_{\mathrm{e}}^{1 / \mathrm{n}}
$$


where, $\mathrm{k}_{\mathrm{f}}$ and $\mathrm{n}$ are Freundlich constants, $1 / \mathrm{n}$ is the heterogeneity factor and an indicator of adsorption capacity, becoming more heterogeneous as its value gets farther to one. The linearized form of Equation (9):

$$
\log \mathrm{q}_{\mathrm{e}}=\log \mathrm{k}_{\mathrm{f}}+1 / \mathrm{nC}_{\mathrm{e}}
$$

where $\mathrm{k}_{\mathrm{f}}$ and $\mathrm{n}$ could be determined from the slope and intercept of the linearized plot [50]. The correlation coefficient $\left(\mathrm{r}^{2}\right)$ can be evaluated by plotting $\ln \left(\mathrm{q}_{\mathrm{e}}\right)$ versus $\ln \left(\mathrm{C}_{\mathrm{e}}\right)$ [104].

\subsection{The Langmuir Model}

The Langmuir adsorption isotherm model was originally used to explain the chemistry of a pure gas on a nonporous surface and the physisorption of a pure gas or a gas mixture on micro and mesoporous adsorbents [110]. Langmuir experimental isotherm suggested an adsorption theory on a flat surface based on kinetic considerations, where there was a continuous process of molecular bombardment on the surface and subsequent desorption to maintain zero accumulation frequency on the surface in equilibrium [50]. It is also a model for the adsorption of gases onto solids using the following assumptions [50,98,104]:

(a) Only a monolayer of adsorbed material is formed at peak adsorption. Adsorbed molecules do not deposit on each other and the adsorption sites were the same. (b) The adsorbed molecules did not interact at constant temperature (c) The adsorbent layer was consistent with the same adsorption sites. (d) All adsorption by the same process occurred. The Langmuir is formulated as follows:

$$
\mathrm{q}_{\mathrm{e}}=\frac{\left(\mathrm{q}_{\mathrm{m}} \mathrm{KLC}_{\mathrm{e}}\right)}{\left(1+\mathrm{KLC}_{\mathrm{e}}\right)}
$$

where, $\mathrm{q}_{\mathrm{e}}$ is the equilibrium adsorption capacity $(\mathrm{mg} / \mathrm{g}), \mathrm{q}_{\mathrm{m}}$ and $\mathrm{KL}$ are the maximum adsorption capacity to form a complete monolayer on the surface $(\mathrm{mg} / \mathrm{g})$, and the Langmuir constant related to the energy of adsorption (bonding energy of sorption in L/g), respectively. The linearized form of Langmuir equation is:

$$
\frac{C_{e}}{q_{e}}=\frac{1}{q_{m} K L}+\frac{C_{e}}{q_{m}}
$$

where $q_{m}$ and KL could be determined from the slope and intercept of linearized equation plot $\left(\frac{C_{e}}{q_{e}}\right.$ against $\left.\mathrm{C}_{\mathrm{e}}\right)[50,111]$.

The dimensionless characteristic of Langmuir isotherm referring to the separation factor $\left(\mathrm{R}_{\mathrm{L}}\right)$ is useful in predicting the adsorption efficiency of the adsorption process. It is an indicator of Langmuir isotherm suitability as either unfavorable $\left(R_{L}>1\right)$, linear $\left(R_{L}=1\right)$, favorable $\left(0<R_{L}<1\right)$, or irreversible $\left(R_{L}=0\right) ; R_{L}$ can be express as: $[3,112]$

$$
\mathrm{R}_{\mathrm{L}}=\frac{1}{1+\mathrm{K}_{\mathrm{L}} \cdot \mathrm{C}_{\mathrm{o}}}
$$

where $C_{o}$ is the highest initial concentration of the adsorbate $(\mathrm{mg} / \mathrm{L})$, and $\mathrm{K}_{\mathrm{L}}(\mathrm{L} / \mathrm{mg})$ is the Langmuir constant.

To justify the appropriateness of a model that best describes the process, the correlation coefficient $\left(\mathrm{r}^{2}\right)$ and nonlinear isotherm plots can be used. Previously, it was demonstrated that the Langmuir isotherm can best describe a developed activated carbon monolith/ $/ \mathrm{Co}_{3} \mathrm{O}_{4}$ adsorbent in the simultaneous $\mathrm{SO}_{2}$ and NOx removal from flue gas [3]. Based on the study, the Langmuir isotherm suitability was shown by the favorable $\mathrm{R}_{\mathrm{L}}$ values of 0.3277 and 0.0097 , and $\mathrm{r}^{2}$ of 0.9759 and 0.9995 for $\mathrm{SO}_{2}$ and NOx; further evidence was shown by the nonlinear isotherm plots as illustrated in Figure 7. The Langmuir isotherm described the experimental data best according to the alignment of the experimental adsorption capacity (q-experiment) with the q-Langmuir when compared to q-Freundlich. Other studies on Pseudo-first order and Pseudo-second order adsorption kinetic models are reported elsewhere [101,111,113]. 

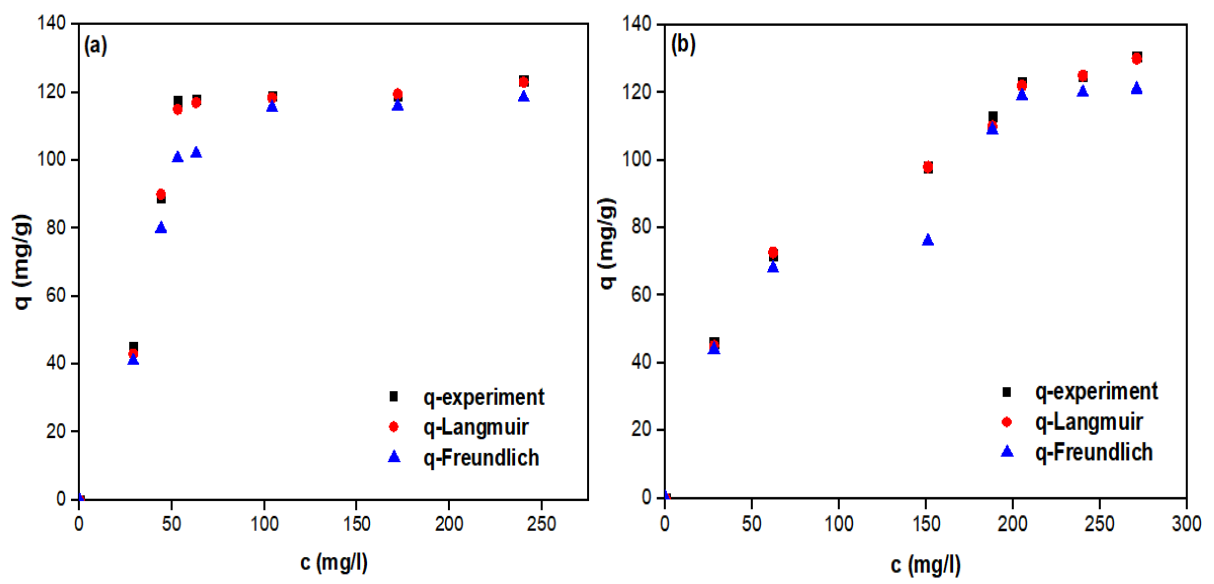

Figure 7. Experimental vs Langmuir and Freundlich isotherms (a) $\mathrm{SO}_{2}$ (b) NOx. Reproduced with permission from Silas et al. [3]. Copyright 2018 Elsevier Ltd. [3].

\subsection{Pressure Drop, Mass Transfer and Heat Transfer in Monolith}

Pressure drop is defined as the energy dissipated as a result of fluid flow through a reactor bed. Due to wall friction, orifice effect in the entry region and between the monolith stacks, gas phase acceleration and pressure fall as a result of the gas-liquid distributor, and pressure drops may occur in the monolith [39]. The monolith has the advantages of a large surface area and uniform flow distribution, hence it overcome the pressure-drop concern, which can mitigate investment and operation costs.

Mass transfer studies are rather scarce and incomplete concerning monolith structures [82]. In general, molecules diffuse to the interior of the adsorbent by radial concentration gradient and the molecular diffusion occurs in two ways: [114,115]

1. Pore diffusion occurs as ordinary diffusion when the pore diameter of the adsorbent is large compared to the mean free path of the adsorbed molecule or as Knudsen diffusion when the pores are much smaller than the mean free path of the gas. The diffusion can also occur in the adsorption process as both ordinary and Knudsen diffusions.

2. Surface diffusion: molecules are adsorbed and transported from one site to another along the pore wall in the direction of decreasing concentration, however surface diffusion may be ignored as it contributes little to the overall transportation.

The structural form of a porous catalytic pellet consists of a large number of irregularly shaped pores interconnected [115]. When the catalyst temperature goes higher, the amount adsorbed decreases but for a constant temperature and fixed adsorbate concentration; an equation for the rate of adsorption is given as: [116]

$$
\frac{d \alpha}{d \tau}=k(1-\alpha)^{n}=A e^{-E / R T}(1-\alpha)^{n}
$$

where, $k, \alpha, n, A, E, R, T$, are rate constant of the adsorption, fractional weight at time $\tau$, reaction order, activation energy, gas constant, absolute temperature respectively. In addition,

$$
\alpha=\frac{w_{f}-w}{w_{f}-w_{o}}
$$

where, $w_{o}$ is initial weight, $w$ is actual weight, and $w_{f}$ final weight, finally, integrating Equation (16) for $n=1$ and $n \neq 1$ yield Equations (15) and (16):

$$
\begin{gathered}
-\ln (1-\alpha)=k \tau \\
\frac{[1-(1-\alpha)]}{(1-n)} \exp 1-n=k \tau
\end{gathered}
$$


The feed gas flows axially, while mass and energy are transferred through the monolith stream in both axial and radial directions [117]. Accordingly, the convective heat transfer prevails, while conduction is negligible due to point contacts between pellets in pellet catalysts, however conduction heat transfer dominates in the parallel channels of the monolith catalyst as an alternative mechanism by radial and axial heat transport $[118,119]$. Therefore, radial heat exchange between the monolithic channels is not possible, no convective heat transfer takes place in this direction [113]. An estimated axial heat conductivity is established for the monolith and presented as: $[118,120]$

$$
k \mathrm{e}, \mathrm{a}=k_{\mathrm{s}}(1-\varepsilon)
$$

where, $k e$, a is the effective axial heat conductivity of monolith substrates, $k_{\mathrm{s}}$ is the intrinsic thermal conductivity of the support material and $\varepsilon$ is the monolith void fraction (or open frontal area, OFA). The radial conductivity $k e, r$ is given as:

$$
k e, r=k_{\mathrm{s}} \frac{(1-\varepsilon)}{(1+\varepsilon)}
$$

A highly conductive material enhances radial heat transfer (i.e., monolith structure) and in return reduces thermal runaway risk with the improvement of thermal stability in catalyst [119]. Theoretical analysis showed low heat transfer efficiency of commercial monolithic structures made of corrugated metal sheets due to their structural characteristics depending on the heat transfer properties of the substrate [121]. Yashnik et al. [122] expressed the Nusselt number inside monolith channels as:

$$
h \mathrm{GS}=\frac{N U \mathrm{CKG}}{d \mathrm{~h}, \mathrm{c}}
$$

where, $\mathrm{c}=0.571\left(\operatorname{Rec} \frac{d \mathrm{~h}, \mathrm{c}}{L}\right)^{2 / 3}$.

\section{Catalyst Application}

The most toxic gases emitted into the atmosphere in the process of fossil fuel combustion are $\mathrm{SO}_{2}$ and NOx [9]. The secondary pollutants from $\mathrm{SO}_{2}$ and $\mathrm{NOx}$ include $\mathrm{H}_{2} \mathrm{SO}_{4}, \mathrm{O}_{3}, \mathrm{HNO}_{3}$ and fine particles (PM2.5); they are harmful to humans and to the natural environment [1]. In the field of air pollution control, the recent priority research areas are in the design of desulfurization and denitrification technologies [123]. Figure 8 is showing the global share (\%) of fuel for electricity generation.

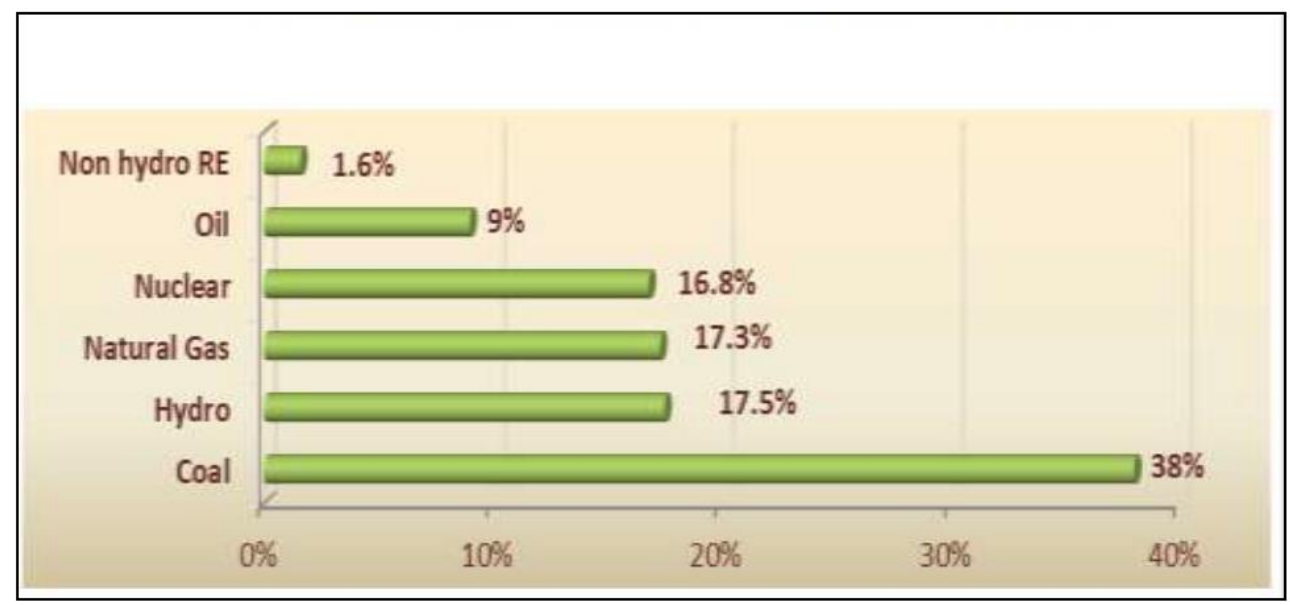

Figure 8. Global share (\%) of fuel for electricity generation. Reproduced with permission from Sinha \& Chattopadhyay [11]. Copyright 2016 International Journal for Innovative Research in Science \& Technology (IJIRST) [11]. 


\section{1. $\mathrm{SO}_{2}$ Removal from Flue Gas}

$\mathrm{SO}_{2}$ is a colorless and toxic gas that can be oxidized to form sulfuric acid when mixed with water and is one of the main contaminants in the composition of flue gas [124]. The combustion of fossil fuel in manufacturing and power plants accounts for $13.6 \%$ and $69.7 \%$, respectively, of global $\mathrm{SO}_{2}$ emissions [10]. Furthermore, $\mathrm{SO}_{2}$ generates aerosols and is the main cause of acid rain which caused considerable damages to properties and the global environment [1]. The convectional technology for $\mathrm{SO}_{2}$ removal from flue gas is the wet flue gas desulfurization (WFGD). Furthermore, the use of liquid-gas reactions and gas-solid reactions with calcites or dolomites as solvents are reported in the literature [125]. Figure 9 shows a typical flue gas desulfurization (FGD) system.

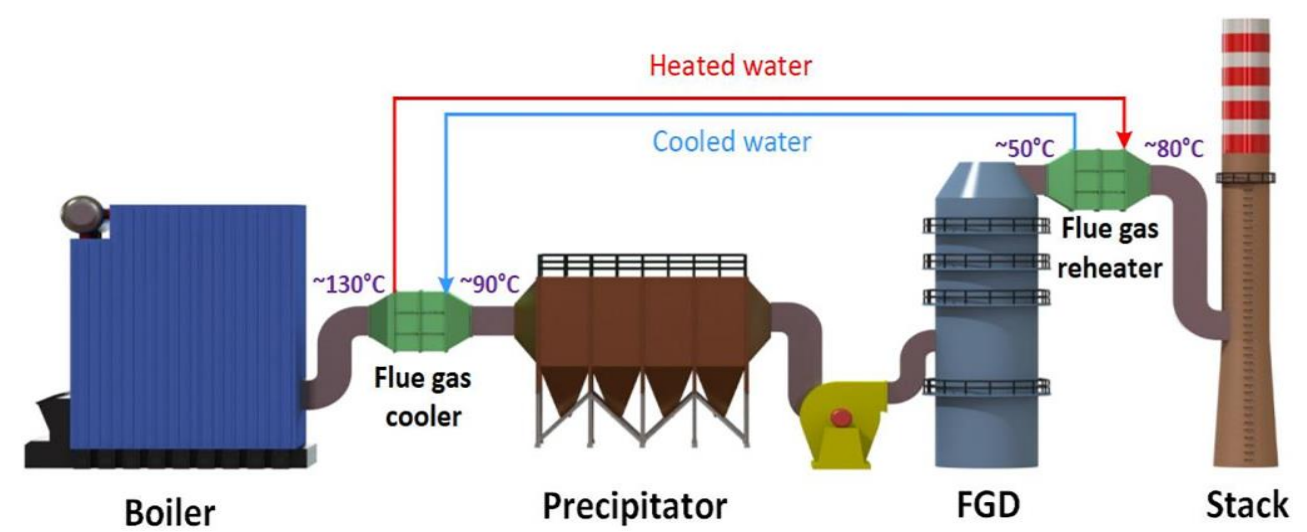

Figure 9. The back end of a coal-fired heating plant. Reproduced with permission from Pan et al. [126]. Copyright 2018 Elsevier Ltd. [126].

The $\mathrm{SO}_{2}$ adsorption at stack temperature may lead to the low removal rates. Wet FGD is associated with the production of wastewater in coal-fired power plants and the liquid-solid droplets caused by FGD desulfurized flue gas may be deposited on the corrosion samples [127]. The byproducts from the wet FGD process, such as gypsum, ammonia sulfate or magnesium sulfate, are considered as a burden being secondary pollutants [1]. The FGD process is also non-regenerable, so it could be assumed as turning the problem of air pollution into a problem of solid or liquid pollution $[14,128,129]$.

\subsection{NOx Removal from Flue Gas}

The term NOx is referred to as the oxides of nitrogen ( $\mathrm{NO}, \mathrm{NO}_{2}, \mathrm{NO}_{3}, \mathrm{~N}_{2} \mathrm{O}_{3}, \mathrm{~N}_{2} \mathrm{O}_{4}, \mathrm{~N}_{2} \mathrm{O}_{5}, \mathrm{NO}$, and $\mathrm{NO}_{2}$ ) [10]. $\mathrm{NO}_{2}$ comprises of $95 \%$ of $\mathrm{NOx}$ produced as a result of combustion processes and is stated to contribute to air emissions by several researchers $[81,124,130] . \mathrm{NO}_{2}$ is a red-brown gas that can readily form nitric acid when it is reacted with $\mathrm{H}_{2} \mathrm{O}$. Among others, photochemical smog and formation of acid rain are the problems caused as a result of $\mathrm{NO}$ oxidation to $\mathrm{NO}_{2}$ in air [1].

The selective catalytic reduction (SCR) technology is matured and widely favored among other technologies used in the NOx removal process [1,64]. In a typical denitrification process, urea $\left(\mathrm{CO}\left(\mathrm{NH}_{2}\right)_{2}\right)$ or ammonia $\left(\mathrm{NH}_{3}\right)$ is injected into flue gas stream to reacts with $\mathrm{NOx}$ at about $350{ }^{\circ} \mathrm{C}$ to produce nitrogen $\left(\mathrm{N}_{2}\right)$ and water [131]. However, at temperatures $<350{ }^{\circ} \mathrm{C}$, ammonium sulfates such as $\mathrm{NH}_{4} \mathrm{SO}_{4}$ can be formed due to $\mathrm{SO}_{2}$ reaction with $\mathrm{NH}_{3}$ in the presence of $\mathrm{H}_{2} \mathrm{O}$ and $\mathrm{O}_{2}$, while its accumulation on the catalyst active site can lead to catalyst deactivation [132].

Kasaoka et al. [133] demonstrated the reduction of $\mathrm{NOx}$ in flue gas to $\mathrm{N}_{2}$ with $\mathrm{NH}_{3}$ by a dry process at $350{ }^{\circ} \mathrm{C}$ and in a wet process where SO was absorbed at around $50{ }^{\circ} \mathrm{C}$ with wastewater byproduct. According to the following expressions, the NO removal efficiency can be achieved in the presence of oxygen [134].

$$
\begin{gathered}
4 \mathrm{NO}+4 \mathrm{NH}_{3}+\mathrm{O}_{2} \rightarrow 8 \mathrm{~N}+6 \mathrm{H}_{2} \mathrm{O} \\
6 \mathrm{NO}_{2}+8 \mathrm{NH}_{3} \rightarrow 7 \mathrm{~N}_{2}+12 \mathrm{H}_{2} \mathrm{O}
\end{gathered}
$$




$$
\mathrm{NO}+\mathrm{NO}_{2}+2 \mathrm{NH}_{3} \rightarrow 2 \mathrm{~N}_{2}+3 \mathrm{H}_{2} \mathrm{O}
$$

$\mathrm{SO}_{2}$ reacts with the water in the flue gas and urea to form sulfuric acid.

$$
\begin{gathered}
\mathrm{SO}_{3}+\mathrm{H}_{2} \mathrm{O} \rightarrow \mathrm{H}_{2} \mathrm{SO}_{4} \\
\mathrm{NH}_{3}+\mathrm{SO}_{3}+\mathrm{H}_{2} \mathrm{O} \rightarrow\left(\mathrm{NH}_{4}\right) \cdot \mathrm{HSO}_{4} \\
2 \mathrm{NH}_{3}+\mathrm{SO}_{3}+\mathrm{H}_{2} \mathrm{O} \rightarrow\left(\mathrm{NH}_{4}\right)_{2} \mathrm{SO}_{4}
\end{gathered}
$$

The denitrification technique by the SCR system is associated with poor catalyst durability, ammonia slip, low NOx reduction, and a high temperature requirement [10]. Figure 10 is showing conventional selective catalytic reduction technology.

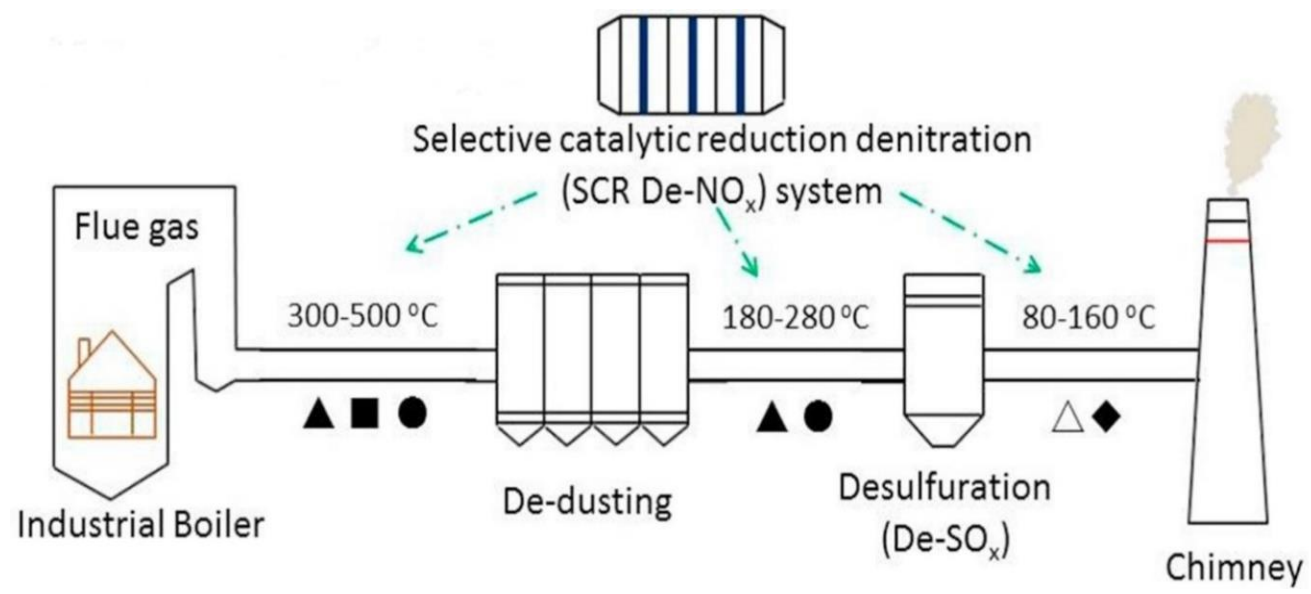

Figure 10. Conventional selective catalytic reduction technology. Reproduced with permission from Wang et al. [135]. Copyright 2018 Elsevier Ltd. [135].

The WFGD and SCR for $\mathrm{SO}_{2}$ and NOx reduction are the most widely used technology for desulfurization/denitrification, however they are expensive $[1,136]$. It is therefore necessary to develop cost-effective methods that can simultaneously capture the pollutants.

\subsection{Simultaneous $\mathrm{SO}_{2} / \mathrm{NOx}$ Removal from Flue Gas}

The requirement of emission standards for $\mathrm{SO}_{2}$ and $\mathrm{NOx}$ in thermal power plants recently is rigorous $\left(35 \mathrm{mg} / \mathrm{m}^{3}\right)$ [137]. Dry carbon-based desulfurization does not emit secondary pollutants, with benefits through the production of elemental sulfur, feasible simultaneous $\mathrm{SO}_{2}$, and $\mathrm{NOx}$ removal, cheaper investment than wet scrubbing that requires a wastewater treatment system and poor extraction efficiency of dry scrubbing $[7,8,114]$. Due to high efficiency in operation, the wet process is used more commonly where calcareous or lime-based scrubbing is utilized, but these approaches are non-regenerational with the transformation of air pollution problem into a problem of solid or liquid emissions $[8,14,138]$.

The multistep reduction is particularly complex with high capital cost, solvent losses, undesired foaming, flooding, fouling of equipment, and corrosion [9]. Therefore, it is better to integrate two or more separation processes into a simultaneous removal of $\mathrm{SO}_{2}$, and $\mathrm{NOx}$ from flue gas in order to increase efficiency and address the stated concerns.

Ye et al. [44] reported the simultaneous removal of $\mathrm{SO}_{2}$ and $\mathrm{NO}$ from flue gases at $350-400{ }^{\circ} \mathrm{C}$ with the space velocity (GHSV) of $2800 \mathrm{~h}^{-1}$ and inlet gas containing $1960 \mathrm{ppm} \mathrm{SO}_{2}$ and $500 \mathrm{ppm}$ NO. Previous study showed that $5 \% \mathrm{NH}_{3}$ at $400{ }^{\circ} \mathrm{C}$ can directly convert $\mathrm{SO}_{2}$ that is regenerated from 
catalyst into solid ammonium sulfur salts [139]. The removal efficiencies of $\mathrm{SO}_{2}$ and $\mathrm{NO}$, respectively, were defined as: [8]

$$
\begin{aligned}
\mathrm{SO}_{2} & =\frac{\mathrm{SO}_{2_{\text {in }}}-\mathrm{SO}_{2_{\text {out }}}}{\mathrm{SO}_{2_{\text {in }}}} 100, \\
\mathrm{NO}_{2} & =\frac{\mathrm{NO}_{\text {in }}-\mathrm{NO}_{\text {out }}}{\mathrm{NO}_{\text {in }}} 100 \%
\end{aligned}
$$

Much of the literature gave detailed descriptions on the issues of $\mathrm{SO}_{2}$ and $\mathrm{NOx}$ removal [139-146]. Table 5 shows some experimental work available in literature on the simultaneous NOx/SOx removal studies.

\begin{tabular}{|c|c|c|}
\hline Objective/Comment & Catalytic Activity & Ref. \\
\hline $\begin{array}{l}\text { Simultaneous removal of } \mathrm{NO} \text { and } \\
\mathrm{SO}_{2} \text { from flue gas catalysts/uses } \\
\text { simulated flue gas. }\end{array}$ & $\begin{array}{l}0.8 \mathrm{~g} \text { of catalyst was used with reaction gas } \\
\text { flow rate of } 500 \mathrm{~cm}^{3} \mathrm{~min}^{-1} \text { corresponding to } \\
\text { gas hourly space velocity (GHSV) of } \\
30,000 \mathrm{~h}^{-1} . \mathrm{N}_{2} \text {-based gas mixture containing } \\
500 \mathrm{ppm} \mathrm{NO}^{\mathrm{N}} 600 \mathrm{ppm} \mathrm{NH}_{3} \text {, and } 1000 \mathrm{ppm} \\
\qquad \mathrm{SO}_{2} \text { and } 0-5 \% \mathrm{O}_{2} \text {. }\end{array}$ & [44] \\
\hline $\begin{array}{l}\text { Vanadia based SCR catalyst } \\
\text { study/uses simulated flue gas. }\end{array}$ & $\begin{array}{l}\text { The reactive gas flow, containing } 1000 \text { ppm of } \\
\left.\text { NOx ( } 100 \mathrm{ppm} \mathrm{NO}_{2} \text { and } 900 \mathrm{ppm} \mathrm{NO}\right) \text {, } \\
1000 \mathrm{ppm} \text { of } \mathrm{NH}_{3}, 15 \% \text { of } \mathrm{O}_{2} \text {, and } 8 \% \text { of } \mathrm{H}_{2} \mathrm{O} \\
\text { at flow rate of } \mathrm{GHSV}=55,000 \mathrm{~h}^{-1} \text {. }\end{array}$ & [147] \\
\hline $\begin{array}{l}\text { Ammonium sulfate salt } \\
\text { deactivation in SCR study/uses } \\
\text { simulated flue gas. }\end{array}$ & 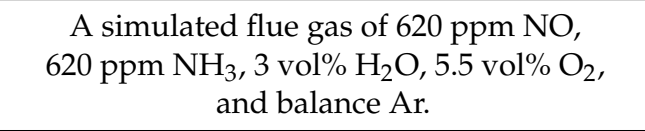 & [54] \\
\hline $\begin{array}{l}\text { Simultaneous removal of } \mathrm{SO}_{2} / \mathrm{NO}_{2} \\
\text { from simulated flue gas. }\end{array}$ & $\begin{array}{l}\text { Simulated flue gas of } 2000 \mathrm{ppm} \text { for } \mathrm{SO}_{2}, 200 \\
\text { ppm for } \mathrm{NO}_{2} \text {, and about } 5 \% \text { for } \mathrm{O}_{2} \text {. The flow } \\
\text { rate was controlled at } 0.15 \mathrm{~m}^{3} \mathrm{~h}^{-1} \text { with } \\
\text { a rotameter. }\end{array}$ & [148] \\
\hline
\end{tabular}

Table 5. Previous works on simultaneous $\mathrm{SO}_{2} / \mathrm{NOx}$ removal.

\section{Regeneration}

The regeneration process eliminates the contaminants that are stored on the surfaces of the sorbents without altering the porosity or causing adsorbent mass losses and restores the adsorptive power. A major problem with the non-regenerative system is the creation of large quantities of waste sludge to be disposed of, and this has become an obstacle. Saturated sorbents are burned or disposed of in landfills, however this choice is an environmental and economic setback. Regenerative processes are carried out to avoid problems associated with the solid waste disposal and to reduce the cost of adsorbent replacement. The spent catalyst may be a source of ultra-fine material to partially substitute cement or be used as a sand replacement [90]. Regeneration is classified into microbiological, chemical, thermal and regeneration with water [140].

The stability of the catalyst and subsequent activity is affected by the regeneration method [7]. Piotrowski et al. [141] found that little information on regeneration kinetics were available. The reversible physical adsorption can be regenerated by reducing the pressure or increasing the adsorbent temperature, while the reduction gas can regenerate an irreversible water-solid reaction mechanism, such as sulfation on a chemical adsorbent [14].

Previous studies have shown that sulfuric deactivated activated carbon can be heated to above $350{ }^{\circ} \mathrm{C}$, and sulfuric acid is reduced to produce concentrated $\mathrm{SO}_{2}$ under inert gases or by heating in a reductive gas flow $\left(\mathrm{NH}_{3}\right.$, urea, $\left.\mathrm{CO}, \mathrm{CH}_{4}, \mathrm{H}_{2}\right)$ [7,42]. $\mathrm{NH}_{3}$ is a favorable reductant for $\mathrm{Al}_{2}\left(\mathrm{SO}_{4}\right)_{3}$ in contrast to $\mathrm{H}_{2}$ and $\mathrm{CH}_{4}$, due to its regeneration potential on the catalyst at the temperatures of the $\mathrm{SO}_{2}$ removal $\left(400^{\circ} \mathrm{C}\right)[142]$. 
It is possible to further transform the off-gas regenerator into sulphuric acid or elemental sulphur $[10,143]$. Desulfation of $\mathrm{CuO} / \gamma-\mathrm{Al}_{2} \mathrm{O}_{3}$ adsorbent can be carried out through the Claus process, under reduced flow of $\mathrm{H}_{2}, \mathrm{CH}_{4}$, and $\mathrm{NH}_{3}$, while desorbed $\mathrm{SO}_{2}$ is converted into sulfuric acid by further oxidation or elemental sulfur [144]. Regeneration has been found to serve three functions in $\mathrm{SO}_{2}$ and $\mathrm{NO}$ removal by $\mathrm{NH}_{3}$; desorption of the adsorbed sulfur particles, surface alteration (chemical effect), and $\mathrm{NH}_{3}$ preservation on the surface (physical effect) that promotes significant removal of $\mathrm{NO}$ at lower temperatures [139].

Air as a regenerating agent is cheap and requires simpler regeneration systems than using ozone $\left(\mathrm{O}_{3}\right)$; however, $\mathrm{O}_{3}$ can remove pollutants at ambient temperature [140], where temperature is reported to be probably the most critical parameter in regeneration [145]. Previously, Jia et al. [146] described the removal of coke from zeolites at low temperatures.

The pretreatment of catalyst before regeneration is recommended with deionized water and sulfuric acid $(\mathrm{pH}=2)$ washing followed by drying at $60^{\circ} \mathrm{C}$ for $10 \mathrm{~h}$ [149]. Poisoned catalysts can hardly be regenerated; therefore, poisoned content of the feed must be decreased to acceptable levels [79]. The regeneration efficiency is the measurement and comparison of the amounts of adsorbate retained by the regenerated and the original adsorbent after adsorptions under the same conditions.

$$
R E=\frac{q_{\text {reg }}}{q_{\text {orig }}} 100 \%
$$

where, $q_{\text {reg }}$ and $q_{\text {orig }}$ are the adsorption capacities per unit of mass of the regenerated and the original adsorbent, respectively [140].

Dey and Dhal [97] found that the regeneration can restore the catalyst's active sites and brings the catalyst to its original state or one of even higher activity. The illustration of the regeneration of hopcalite catalysts after $\mathrm{CO}$ oxidation is presented in Figure 11.

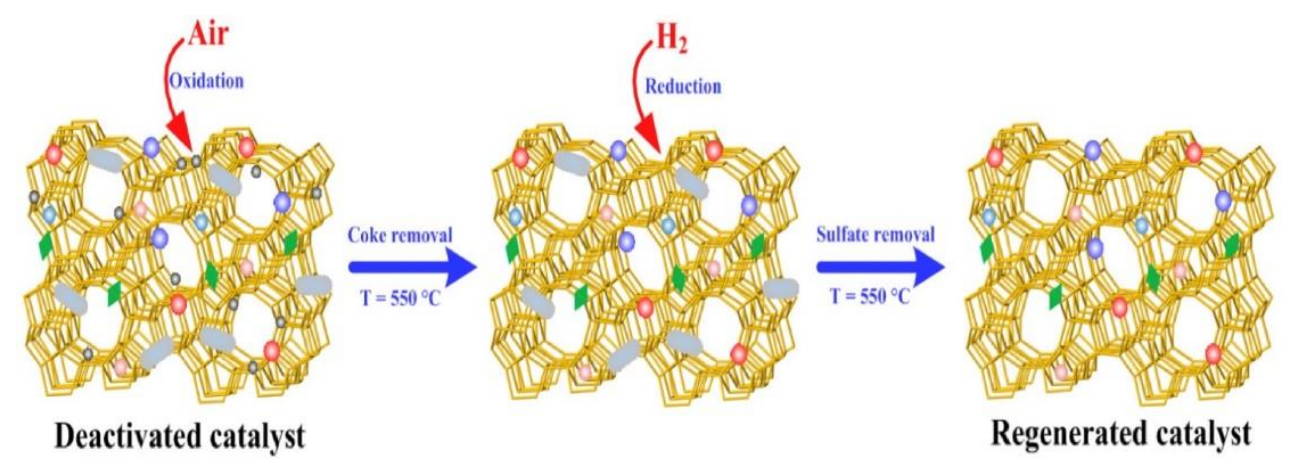

Figure 11. Regeneration of hopcalite catalysts after CO oxidation. Reproduced with permission from Dey and Dhal [97]. Copyright 2019 Elsevier Ltd. [97].

The reaction activity of hopcalite is presented as:

$$
\mathrm{CO}+\mathrm{Mn}^{4+} \rightarrow \mathrm{CO}^{+}{ }_{\text {dds }}+\mathrm{Mn}^{3+}
$$

The promotion of $\mathrm{Cu}$ has further been associated to the reduction of $\mathrm{O}_{2}$ :

$$
1 / 2 \mathrm{O}_{2}+\mathrm{Cu}^{1+} \rightarrow \mathrm{CO}_{2}
$$

The oxidation occurs by the process:

$$
\mathrm{O}^{-}{ }_{\text {ads }}+\mathrm{CO}^{+}{ }_{\text {ads }} \rightarrow \mathrm{CO}_{2}
$$


The resonance reaction system brings the catalyst back to the active state:

$$
\mathrm{Cu}^{1+}+\mathrm{Mn}^{3+} \rightleftarrows \mathrm{Cu}^{1+}+\mathrm{Mn}^{4+}
$$

The catalyst V/AC was used for $\mathrm{SO}_{2}$ capture, and the experiment was terminated when the $\mathrm{SO}_{2}$ removal efficiency decreased to $80 \%$ and the workers performed thermal regeneration at $300-400{ }^{\circ} \mathrm{C}$ for $1 \mathrm{~h}$ under $\mathrm{N}_{2}(400 \mathrm{~mL} / \mathrm{min})$ then further conducted $\mathrm{CO}$ regeneration at $300-400{ }^{\circ} \mathrm{C}$ in a furnace for 1 $\mathrm{h}$ under $0.15 \% \mathrm{CO}$ [7]. The thermal swing adsorption (TSA) is a process where desorption is achieved by increasing the system temperature while decreasing the pressure; the process is called pressure swing adsorption (PSA) [86].

Contaminants are desorbed in the reverse order or countercurrent to which they adsorbed in a co-current method in monolith, the post regeneration activity follows: drying at $60{ }^{\circ} \mathrm{C}$ for $2 \mathrm{~h}$ and then at $120^{\circ} \mathrm{C}$ for $2 \mathrm{~h}$ [150]. Several studies demonstrated the regeneration of catalysts [7,41,151-153].

\section{Overview on Fluidized-Bed/Fixed-Bed Reactors for Activity Test}

When the fluid carrying channel(s) has size below $1 \mathrm{~mm}$, the reactors are regarded as being micro-structured [154], and a good example is the monolith. Experimental data in the laboratory (i.e., kinetics, adsorption capacity) using fluidized or fixed-bed reactors can help in understanding best how the system works [115]. Most of the two mainly used reactor types for flue gas cleaning laboratory research are the fluidized-bed and fixed-bed reactors. Table 6 showed the merits and demerits of each reactor.

Table 6. Comparison of the fluidized-bed reactors and fixed-bed reactors.

\begin{tabular}{|c|c|c|}
\hline $\begin{array}{c}\text { Fluidized-Bed Reactors (+Merit, } \\
\text {-Demerit) }\end{array}$ & Fixed-Bed Reactors (+Merit, -Demerit) & Ref. \\
\hline $\begin{array}{c}(+) \text { Fly ash passes through the reactor } \\
\text { without plugging }\end{array}$ & $\begin{array}{l}\text { (-) Plugging can occur (monolith } \\
\text { adsorbent/catalyst reactor remedy) }\end{array}$ & {$[5,80,155-157]$} \\
\hline (-) Higher pressure drop & (+) Simple and robust construction & \\
\hline $\begin{array}{l}\text { (+) Shutdown for replacement of catalyst } \\
\text { is not needed. }\end{array}$ & $\begin{array}{l}\text { (-) Process must be shut down for } \\
\text { reloading the reactor with fresh catalyst }\end{array}$ & \\
\hline (-) Possible attrition of the bed material & (+) Pressure drop is low & \\
\hline \multirow[t]{2}{*}{$\begin{array}{c}\text { (+) Continuous operation and } \\
\text { regeneration }\end{array}$} & $\begin{array}{l}\text { (-) Bad temperature distribution, Low } \\
\text { specific capacity }\end{array}$ & \\
\hline & $\begin{array}{l}\text { (+) Lots of processes for different } \\
\text { applications in operation }\end{array}$ & \\
\hline $\begin{array}{c}\text { (+) High thermal/mass transfer coefficient, } \\
\text { high gas/solid, and solid/solid contact } \\
\text { areas are continuous }\end{array}$ & (-) Long period to heat-up & \\
\hline (+) No valve problems & $\begin{array}{l}\text { (-) Valves are required to isolate the } \\
\text { regenerator's absorber }\end{array}$ & \\
\hline $\begin{array}{c}\text { (+) Less space requirement because of } \\
\text { great scale-up }\end{array}$ & $(+)$ Can operate at partial load $(20 \pm 110 \%)$ & \\
\hline
\end{tabular}

\section{Conclusions}

The development of a catalyst that can clean up large volumes of flue gases with valuable byproducts such as sulfuric acid with environmental consideration through the elimination of the waste materials and proper disposal have gained a lot of attention. Such a catalyst should be compatible and easily retrofitted to the existing power plants, fired boilers, incinerators, and other chemical process industries with more than $90 \%$ efficiency regeneration. Moreover, high surface area with abundant active site and chemical nature are stringent characteristics of any catalyst to perform 
effectively. In this study, the basis of developing a monolithic supported metal-oxide-based catalyst for environmental application was explored. The possibilities of catalyst deactivation, regeneration, and practical environmental application in SOx and NOx removal from flue gas were discussed.

Author Contributions: Conceptualization, K.S. and U.R.; methodology, K.S. and U.R.; validation, K.S.; W.A.W.A.K.G. and U.R.; investigation, K.S. and U.R.; resources, K.S., W.A.W.A.K.G. and U.R.; data curation, K.S.; writing — original draft preparation, K.S. and U.R.; writing—review and editing, K.S., W.A.W.A.K.G., T.S.Y.C., and U.R.; visualization, K.S. and U.R.; supervision, W.A.W.A.K.G., T.S.Y.C., and U.R.; project administration, W.A.W.A.K.G., T.S.Y.C., and U.R.; funding acquisition, W.A.W.A.K.G. All authors have read and agreed to the published version of the manuscript.

Funding: This research was funded by Universiti Putra Malaysia (UPM) grant number GP-IPB/2016/9515201 and APC was funded by Research Management Center (RMC), Universiti Putra Malaysia (UPM), Malaysia.

Acknowledgments: The authors would like to gratefully acknowledge Universiti Putra Malaysia (UPM) for the financial support of this work (via Geran Putra-IPB, UPM GP-IPB/2016//9515200, GP-IPB/2016/9515201, and GP-IPB/2016/9515202).

Conflicts of Interest: The authors declare no conflict of interest.

\section{Nomenclature}

$\begin{array}{ll}\mathrm{ACM} & \text { Activated Carbon Monolith } \\ \mathrm{AC} & \text { Activated Carbon } \\ \mathrm{CO}_{2} & \text { Carbon Dioxide } \\ \mathrm{MO} & \text { Metal Oxide } \\ \mathrm{NOx} & \text { Nitrogen Oxide } \\ \mathrm{q} & \text { Adsorption Capacity } \\ \mathrm{RE} & \text { Regeneration Efficiency } \\ \mathrm{SCR} & \text { Selective Catalytic Reduction } \\ \mathrm{SO}_{2} & \text { Sulfur dioxide } \\ \text { WFGD } & \text { Wet Flue Gas Desulphurization }\end{array}$

\section{References}

1. Cheng, G.; Zhang, C. Desulfurization and denitrification technologies of coal-fired flue gas. Pol. J. Environ. Stud. 2018, 272, 481-489. [CrossRef]

2. Koplitz, S.N.; Jacob, D.J.; Sulprizio, M.P.; Myllyvirta, L.; Reid, C. Burden of disease from rising coal-fired power plant emissions in Southeast Asia. Environ. Sci. Technol. 2016, 51, 1-10. [CrossRef]

3. Kiman, S.; Ghani, W.A.W.A.K.; Choong, T.S.Y.; Rashid, U. Breakthrough studies of $\mathrm{Co}_{3} \mathrm{O}_{4}$ supported activated carbon monolith for simultaneous $\mathrm{SO}_{2} / \mathrm{NOx}$ removal from flue gas. Fuel Process. Technol. 2018, 180, 155-165.

4. Lee, D.W.; Yoo, B.R. Metal oxide (supported) catalysts: Synthesis and applications. J. Ind. Eng. Chem. Adv. 2014, 20, 3947-3959. [CrossRef]

5. Rau, J.Y.; Tseng, H.H.; Chiang, B.C.; Wey, M.Y.; Lin, M.D. Evaluation of $\mathrm{SO}_{2}$ oxidation and fly ash filtration by an activated carbon fluidized-bed reactor: The effects of acid modification, copper addition and operating condition. Fuel 2010, 89, 732-742. [CrossRef]

6. Hu, H.; Wang, S.; Zhang, X.; Zhao, Q.; Li, J. Study on simultaneous catalytic reduction of sulfur dioxide and nitric oxide on rare earth mixed compounds. J. Rare Earths 2006, 24, 24695-24698. [CrossRef]

7. Hou, Y.; Zhang, R.; Han, X.; Huang, Z.; Cui, Y. The mechanism of CO regeneration on $\mathrm{V}_{2} \mathrm{O}_{5} / \mathrm{AC}$ catalyst and sulfur recovery. Chem. Eng. J. 2017, 316, 744-750. [CrossRef]

8. Liu, Z.S. Adsorption of $\mathrm{SO}_{2}$ and $\mathrm{NO}$ from incineration flue gas onto activated carbon fibers. Waste Manag. 2008, 28, 2329-2335. [CrossRef]

9. Hajari, A.; Atanga, M.; Hartvigsen, J.L.; Rownaghi, A.A.; Rezaei, F. Combined flue gas cleanup process for simultaneous removal of SOx, NOx, and $\mathrm{CO}_{2}$ : A techno-economic analysis. Energ. Fuels 2017, 31, 4165-4172. [CrossRef]

10. Liu, Y.; Bisson, T.M.; Yang, H.; Xu, Z. Recent developments in novel sorbents for flue gas clean up. Fuel Process. Technol. 2010, 91, 1175-1197. [CrossRef] 
11. Sinha, S.; Chattopadhyay, S. A study on application of renewable energy technologies for mitigatting the adverse environmental impacts generated from power generation units in Himalayan region. Int. J. Innov. Res. Sci. Technol. 2016, 3, 212-232.

12. Hosseini, S.; Marahel, E.; Bayesti, I.; Abbasi, A.; Abdullah Choong, C.T.S.Y. $\mathrm{CO}_{2}$ adsorption on modified carbon coated monolith: Effect of surface modification by using alkaline solutions. Appl. Surf. Sci. 2015, 324, 569-575. [CrossRef]

13. Ma, S.; Zhao, Y.; Yang, J.; Zhang, S.; Zhang, J.; Zheng, C. Research progress of pollutants removal from coal-fired flue gas using non-thermal plasma. Renew. Sustain. Energ. Rev. 2017, 67, 791-810. [CrossRef]

14. Lin, Y.S.; Deng, S.G. Removal of trace sulfur dioxide from gas stream by regenerative sorption processes. Sep. Purif. Technol. 1998, 13, 65-77. [CrossRef]

15. Gupta, A.; Gaur, V.; Verma, N. Breakthrough analysis for adsorption of sulfur-dioxide over zeolites. Chem. Eng. Process. Process Intensif. 2004, 43, 9-22. [CrossRef]

16. Trimm, D.L. The regeneration or disposal of deactivated heterogeneous catalysts. Appl. Catal. A Gen. 2001, 212, 153-160. [CrossRef]

17. Jia, L.Y.; AlFarouha, L.; Pinard, S.; Hedan, J.D.; Comparot, A.; Dufour, K.; Ben, T.H.; Vezin, C.; Batiot, D. Environmental new routes for complete regeneration of coked zeolite. Appl. Catal. B Environ. 2017, 219, 82-91. [CrossRef]

18. Tsybulevski, A.M.; Tkachenko, O.P.; Rode, E.J.; Weston, K.C.; Kustov, L.M.; Sulman, E.M.; Doluda, V.Y.; Greish, A.A. Reactive adsorption of sulfur compounds by transition metal polycation exchanged zeolites and desulfurization of hydrocarbon streams. Energ. Technol. 2017, 5, 1627-1637. [CrossRef]

19. Ju, F.; Liu, C.; Li, K.; Meng, C.; Gao, S.; Ling, H. Reactive adsorption desulfurization of FCC gasoline over a Ca-Doped Ni-ZnO/Al ${ }_{2} \mathrm{O}_{3}-\mathrm{SiO}_{2}$. Energ. Fuels 2016, 30, 6688-6697. [CrossRef]

20. Tang, L.; Zhao, Z.; Li, K.; Yu, X.; Wei, Y.; Liu, J.; Peng, Y.; Li, Y.; Chen, Y. Highly active monolith catalysts of $\mathrm{LaKCoO}_{3}$ perovskite-type complex oxide on alumina-washcoateddiesel particulate filter and the catalytic performances for the combustion of soot. Catal. Today 2020, 339, 159-173. [CrossRef]

21. Zhang, L.; Jiang, Y.; Chen, B.; Shi, C.; Li, Y.; Wang, C. Exceptional activity for formaldehyde combustion using siliceous beta zeolite as a catalyst support. Catal. Today 2020, 339, 174-180. [CrossRef]

22. Davó-quiñonero, A.; Sorolla-rosario, D.; Bailón-garcía, E.; Lozano-castelló, D. Improved asymmetrical honeycomb monolith catalyst prepared using a 3D printed template. J. Hazard. Mater. 2019, 368, 638-643. [CrossRef] [PubMed]

23. José, M.; Gatica, J.; Castiglioni, C.; Santos, M.; Pilar, Y.; Gustavo, C.; Martín, T.; Hilario, V. Use of pillared clays in the preparation of washcoatedclay honeycomb monoliths as support of manganese catalysts for the total oxidation of VOCs. Catal. Today 2017, 296, 84-94.

24. Tahay, P.; Khani, Y.; Jabari, M.; Bahadoran, F.; Safari, N. Highly porous monolith/ $\mathrm{TiO}_{2}$ supported Cu, Cu-Ni, $\mathrm{Ru}$, and Pt catalysts in methanol steam reforming process for $\mathrm{H}_{2}$ generation. Appl. Catal. A Gen. 2018, 554, 44-53. [CrossRef]

25. Kiman, S.; Ghani, W.A.W.A.K.; Choong, T.S.Y.; Rashid, U. Regeneration/optimization of activated carbon monolith in simultaneous $\mathrm{SO}_{2} / \mathrm{NOx}$ removal from flu gas. Chem. Eng. Technol. 2019, 9, 1928-1940.

26. Sharma, M.; Choudhury, D.; Hazra, S.; Basu, S. Effective removal of metal ions from aqueous solution by mesoporous $\mathrm{MnO}_{2}$ and $\mathrm{TiO}_{2}$ monoliths: Kinetic and equilibrium modelling. J. Alloys Compd. 2017, 720, 221-229. [CrossRef]

27. Darunte, L.A.; Terada, Y.; Murdock, C.R.; Walton, K.S.; Sholl, D.S.; Jones, C.W. Monolith supported amine functionalized $\mathrm{Mg}$ adsorbents for $\mathrm{CO}_{2}$ capture. ACS Appl. Mater. Interfaces 2017, 2, 17042-17050. [CrossRef]

28. Zhu, L.; Tan, C.F.; Gao, M.; Ho, G.W. Design of a metal oxide-organic framework (MoOF) foam microreactor: Solar-induced direct pollutant degradation and hydrogen generation. Adv. Mater. 2015, 27, 7713-7719. [CrossRef]

29. Shen, F.; Liu, J.; Dong, Y.; Wu, D.; Gu, C.; Zhang, Z. Elemental mercury removal from syngas by porous carbon-supported $\mathrm{CuCl}_{2}$ sorbents. Fuel 2019, 239, 138-144. [CrossRef]

30. Abubakar, U.C.; Alhooshani, K.R.; Adamu, S.; Al Thagfi, J.; Saleh, T.A. The effect of calcination temperature on the activity of hydrodesulfurization catalysts supported on mesoporous activated carbon. J. Clean. Prod. 2019, 211, 1567-1575. [CrossRef]

31. Lin, Y.; Li, Y.; Xu, Z.; Xiong, J.; Zhu, T. Transformation of functional groups in the reduction of $\mathrm{NO}_{\text {with }} \mathrm{NH}_{3}$ over nitrogen-enriched activated carbons. Fuel 2018, 223, 312-323. [CrossRef] 
32. Shiung, S.; Rock, L.; Liew, K.; Mun, Y.; Elfina, W. Activated carbon for catalyst support from microwave pyrolysis of orange peel. Waste Biomass Valor. 2017, 8, 2109-2119.

33. Kiman, S.; Ghani, W.A.W.A.K.; Choong, T.S.Y.; Rashid, U. Carbonaceous materials modified catalysts for simultaneous $\mathrm{SO}_{2} / \mathrm{NOx}$ removal from flue gas: A review. Catal. Rev. Sci. Eng. 2019, 61, 134-161.

34. Patton, A.; Crittenden, B.D.; Perera, S.P. Use of the linear driving force approximation to guide the design of monolithic adsorbents. Chem. Eng. Res. Des. 2004, 82, 999-1009. [CrossRef]

35. Kreutzer, M.T.; Du, P.; Heiszwolf, J.J.; Kapteijn, F.; Moulijn, J.A. Mass transfer characteristics of three-phase monolith reactors. Chem. Eng. Sci. 2001, 56, 6015-6023. [CrossRef]

36. Heiszwolf, J.J.; Engelvaart, L.B.; Van den Eijnden, M.G.; Kreutzer, M.T.; Kapteijn, F.; Moulijn, J.A. Hydrodynamic aspects of the monolith loop reactor. Chem. Eng. Sci. 2001, 56, 805-812. [CrossRef]

37. Moreno-Castilla, C.; Pérez-Cadenas, A.F. Carbon-based honeycomb monoliths for environmental gas-phase applications. Materials 2010, 3, 1203-1227. [CrossRef]

38. Boger, T.; Heibel, A.K.; Sorensen, C.M. Monolithic catalysts for the chemical industry. Ind. Eng. Chem. Res. 2004, 43, 4602-4611. [CrossRef]

39. Roy, S.; Bauer, T.; Al-Dahhan, M.; Lehner, P.; Turek, T. Monoliths as multiphase reactors: A review. AIChE J. 2004, 50, 2918-2938. [CrossRef]

40. Hosseini, S.; Rashid, S.A.; Abbasi, A.; Babadi, F.E.; Abdullah, L.C.; Choong, T.S.Y. Effect of catalyst and substrate on growth characteristics of carbon nanofiber onto honeycomb monolith. Rev. Mex. Urol. 2016, 76, 440-449. [CrossRef]

41. Lei, Z.; Long, A.; Jia, M.; Liu, X. Experimental and kinetic study of selective catalytic reduction of NO with $\mathrm{NH}_{3}$ over $\mathrm{CuO} / \mathrm{Al}_{2} \mathrm{O}_{3} /$ cordierite catalyst. Chin. J. Chem. Eng. 2010, 18, 721-729. [CrossRef]

42. Boyano, A.; Lázaro, M.J.; Cristiani, C.; Maldonado-hodar, F.J.; Forzatti, P.; Moliner, R. A comparative study of $\mathrm{V}_{2} \mathrm{O}_{5} / \mathrm{AC}$ and $\mathrm{V}_{2} \mathrm{O}_{5} / \mathrm{Al}_{2} \mathrm{O}_{3}$ catalysts for the selective catalytic reduction of $\mathrm{NO}$ by $\mathrm{NH}_{3}$. Chem. Eng. J. 2009, 149, 173-182. [CrossRef]

43. Campanati, M.; Fornasari, G.; Vaccari, A. Fundamental in the preparation of heterogeneous catalysts. Catal. Today 2003, 77, 299-314. [CrossRef]

44. Liu, Y.; Ning, P.; Li, K.; Tang, L.; Hao, J.; Song, X.; Zhang, G.; Wang, C. Simultaneous removal of NOx and $\mathrm{SO}_{2}$ by low-temperature selective catalytic reduction over modified activated carbon catalysts. Russ. J. Phys. Chem. A 2017, 91, 490-499. [CrossRef]

45. Han, L.; Gao, M.; Hasegawa, J.; Li, S.; Shen, Y.; Li, H.; Shi, L.; Zhang, D. $\mathrm{SO}_{2}$-tolerant selective catalytic reduction of NOx over meso- $\mathrm{TiO}_{2} @ \mathrm{Fe}_{2} \mathrm{O}_{3} @ \mathrm{Al}_{2} \mathrm{O}_{3}$ metal-based monolith catalysts. Environ. Sci. Technol. 2019, 53, 6462-6473. [CrossRef]

46. Mendes, N.; Ozhan, C.; Da Costa, P.; Bacariza, M.C.; Henriques, C. Optimizing washcoatingconditions for the preparation of zeolite-based cordierite monoliths for $\mathrm{NOx} \mathrm{CH}_{4}$-SCR: A required step for real application. Ind. Eng. Chem. Res. 2019, 58, 11799-11810.

47. Li, X.; Zhang, X.; Zhong, L.; Zhang, C.; Fang, Q.; Chen, G. Enhancement of SCR performance of monolithic $\mathrm{Mn}-\mathrm{Ce} / \mathrm{Al}_{2} \mathrm{O}_{3} /$ cordierite catalysts by using modified deposition precipitation method. Asia-Pac. J. Chem. Eng. 2019, 14, e2318. [CrossRef]

48. Qi, K.; Xie, J.; Li, F.; He, F. Experimental study on preparation and operating conditions over a promising monolithic catalyst for NOx removal: $\mathrm{MnOx} / \mathrm{TiO}_{2} /$ cordierite. Mater. Sci. Forum 2017, 898, 1905-1915. [CrossRef]

49. Julkapli, N.M.; Bagheri, S. Graphene supported heterogeneous catalysts: An overview. Int. J. Hydrog. Energy 2014, 40, 948-979. [CrossRef]

50. Teoh, Y.P.; Khan, M.A.; Choong, T.S.Y. Kinetic and isotherm studies for lead adsorption from aqueous phase on carbon coated monolith. Chem. Eng. J. 2013, 217, 248-255. [CrossRef]

51. Ma, Z.; Zaera, F. Heterogeneous catalysis by metals. Encycl. Inorg. Bioinorg. Chem. 2011, 1-17.

52. Zhang, F.; Tian, X.; Shah, M.; Yang, W. Synthesis of magnetic carbonaceous acids derived from hydrolysates of Jatropha hulls for catalytic biodiesel production. RSC Adv. 2017, 7, 11403-11413. [CrossRef]

53. Guo, P.; Huang, F.; Zheng, M. Magnetic solid base catalysts for the production of biodiesel. J. Am. Oil Chem. Soc. 2012, 89, 925-933. [CrossRef]

54. Xue, B.; Luo, J.; Zhang, F.; Fang, Z. Biodiesel production from soybean and Jatropha oils by magnetic. Energy 2014, 68, 584-591. [CrossRef] 
55. Feyzi, M.; Norouzi, L. Preparation and kinetic study of magnetic $\mathrm{Ca} / \mathrm{Fe}_{3} \mathrm{O}_{4} @ \mathrm{SiO}_{2}$ nanocatalysts for biodiesel production. Renew. Energ. 2016, 94, 579-586. [CrossRef]

56. Zhang, F.; Fang, Z.; Wang, Y. Biodiesel production directly from oils with high acid value by magnetic $\mathrm{Na}_{2} \mathrm{SiO} @ \mathrm{Fe}_{3} \mathrm{O}_{4} / \mathrm{C}$ catalyst and ultrasound. Fuel 2015, 150, 370-377. [CrossRef]

57. Fadhil, A.B.; Aziz, A.M.; Al-tamer, M.H. Biodiesel production from Silybummarianum L. seed oil with high FFA content using sulfonated carbon catalyst for esterification and base catalyst for transesterification. Energ. Convers. Manag. 2016, 108, 255-265. [CrossRef]

58. Cao, M.O.; Liu, Y.; Zhang, P.; Fan, M.; Jiang, P. Biodiesel production from soybean oil catalyzed by magnetic. Fuel 2016, 164, 314-321.

59. Stankiewicz, A. Process Intensity, cation in-line monolithic reactor. Chem. Eng. Sci. 2001, 56, 359-364. [CrossRef]

60. Li, J.; Liang, X. Magnetic solid acid catalyst for biodiesel synthesis from waste oil. Energ. Conver. Manag. 2017, 141, 126-132. [CrossRef]

61. Dai, H. Environmental catalysis: A solution for the removal of atmospheric pollutants. Sci. Bull. 2015, 60, 1708-1710. [CrossRef]

62. Ruiz-Martı́nez, E.; Sa'nchez-Herva's, J.M.; Otero-Ruiz, J. Effect of operating conditions on the reduction of nitrous oxide by propane over a Fe-Zeolite monolith. Appl. Catal. B Environ. 2005, 61, 306-315.

63. Radwan, N.R.E.; El-Shall, M.S.; Hassan, H.M.A. Synthesis and characterization of nanoparticle $\mathrm{Co}_{3} \mathrm{O}_{4}, \mathrm{CuO}$ and NiOcatalysts prepared by physical and chemical methods to minimize air pollution. Appl. Catal. A Gen. 2007, 331, 8-18. [CrossRef]

64. Huang, Y.; Gao, D.; Tong, Z.; Zhang, J.; Luo, H. Oxidation of NO over cobalt oxide supported on mesoporous silica. J. Nat. Gas Chem. 2009, 18, 421-428. [CrossRef]

65. Yan, Z.; Wang, J.; Zou, R.; Liu, L.; Zhang, Z.; Wang, X. Hydrothermal synthesis of $\mathrm{CeO}_{2}$ nanoparticles on activated carbon with enhanced desulfurization activity. Energ. Fuels 2012, 26, 5879-5886. [CrossRef]

66. Haakana, T.; Kolehmainen, E.; Turunen, I.; Mikkola, J.P.; Salmi, T. The development of monolith reactors: General strategy with a case study. Chem. Eng. Sci. 2004, 59, 5629-5635. [CrossRef]

67. Kiman, S.; Ghani, W.A.W.A.K.; Choong, T.S.Y.; Rashid, U. Activated carbon monolith $\mathrm{Co}_{3} \mathrm{O}_{4}$ based catalyst: Synthesis, characterization and adsorption Studies. Environ. Technol. Innov. 2018, 12, 273-285.

68. Liu, Y.; Deng, J.; Xie, S.; Wang, Z.; Dai, H. Catalytic removal of volatile organic compounds using ordered porous transition metal oxide and supported noble metal catalysts. CuihuaXuebao/Chin. J. Catal. 2016, 37, 1193-1205. [CrossRef]

69. Neyestanaki, A.K.; Klingstedt, F.; Salmi, T.; Murzin, D.Y. Deactivation of postcombustioncatalysts. A review. Fuel 2004, 83, 395-408. [CrossRef]

70. Kiman, S.; Ghani, W.A.W.A.K.; Choong, T.S.Y.; Rashid, U. Optimization of activated carbon monolith $\mathrm{Co}_{3} \mathrm{O}_{4}$-based catalyst for simultaneous $\mathrm{SO}_{2} / \mathrm{NOx}$ removal from flue gas using response surface methodology. Combust. Sci. Technol. 2020, 192, 786-803.

71. Boyano, A.; Lombardo, N.; Moliner, R. Vanadium-loaded carbon-based monoliths for the on-board NO reduction: Experimental study of operating conditions. Chem. Eng. J. 2008, 144, 343-351. [CrossRef]

72. Boyano, A.; Herrera, C.; Larrubia, M.A.; Alemany, L.J.; Moliner, R.; Lázaro, M.J. Vanadium loaded carbon-based monoliths for the on-board no reduction: Influence of temperature and period of the oxidation treatment. Chem. Eng. J. 2010, 160, 623-633. [CrossRef]

73. Couck, S.; Lefevere, J.; Mullens, S.; Protasova, L.; Meyen, V.; Desmet, G.; Baron, G.V.; Denayer, J.F. CO $\mathrm{CO}_{2}$ $\mathrm{CH}_{4}$ and $\mathrm{N}_{2}$ separation with a 3DFD-printed ZSM-5 monolith. Chem. Eng. J. 2017, 308, 719-726. [CrossRef]

74. Kiel, J.H.A.; Edelaar, A.C.S.; Prins, W.; Van Swaaij, W.P.M. Performance of silica-supported copper oxide sorbents for $\mathrm{SO}_{2} / \mathrm{NOx}$-removal from flue gas. Appl. Catal. B Environ. 1992, 141-160.

75. Bin, H.; Fang, J.T.; Zhao, Y.T.; Fang, J.J.; Huang, Y. Selective oxidation of hydrogen sulfide to sulfur over activated carbon-supported metal oxides. Fuel 2013, 108, 143-148.

76. Nijhuis, T.A.; Kreutzer, M.T.; Romijn, C.J.; Kapteijn, F.; Moulijn, J.A. Monolithic catalysts as efficient three-phase reactors. Chem. Eng. Sci. 2001, 56, 823-829. [CrossRef]

77. Bartholomew, C.H. Mechanism of catalyst deactivation. Appl. Catal. A Gen. 2001, 212, 17-60. [CrossRef]

78. Bartholomew, C.H.; Argyle, M.D. Advances in catalyst deactivation and regeneration. Catalysts 2015, 5, 949-954. [CrossRef]

79. Worstell, J. Catalyst deactivation. Adiabatic Fixed Bed React. 2014, 52, 35-65. 
80. Moulijn, J.A.; Van Diepen, A.E.; Kapteijn, F. Catalyst deactivation: Is it predictable? What to do? Appl. Catal. A Gen. 2001, 212, 3-16. [CrossRef]

81. Kiełtyka, M.; Dias, A.P.S.; Kubiczek, H.; Sarapata, B.; Grzybek, T. The influence of poisoning on the deactivation of Denoxcatalysts. C. R. Chim. 2015, 18, 1036-1048. [CrossRef]

82. Rusu, A.O.; Dumitriu, E. Destruction of volatile organic compounds by catalytic oxidation. Environ. Eng. Manag. J. 2003, 2, 273-302. [CrossRef]

83. Rudyak, V.; Minakov, A. Modeling and optimization of Y-type of micromixer. Micromachines 2009, 33, 75-88. [CrossRef]

84. Marsh, H. Adsorption methods to study microporpsity of coals and carbons. Carbon 1987, 25, 49-58. [CrossRef]

85. Hu, Z.; Srinivasan, M.P.; Ni, Y. Novel activation process for preparing highly microporous and mesoporous activated carbons. Carbon 2001, 39, 877-886. [CrossRef]

86. Hinkov, I.; Deng, J.; Xie, S.; Wang, Z.; Dai, H. Carbon dioxide capture by adsorption. J. Chem. Technol. Metall. 2016, 41, 609-626.

87. Marsh, H.; Rand, B. The characterization of microporous carbons by means of the Dubinin-Radushkevichequation. J. Colloid Interface Sci. 1970, 33, 101-116. [CrossRef]

88. Heigl, N.; Greider, A.; Petter, C.H.; Kolomiets, O.; Sieser, H.W.; Ulbricht, M.; Bonn, G.K.; Huck, C.W. Simultaneous determination of the micro-, meso-, and macropore size fractions of porous polymers by a combined use of fouriertransform hear-infrared diffuse reflection spectroscopy and multivariate techniques. Anal. Chem. 2008, 80, 8493-8500. [CrossRef]

89. Choma, J.; Górka, J.; Jaroniec, M.; Zawislak, A. Development of microporosity in mesoporous carbons. Top. Catal. 2010, 53, 283-290. [CrossRef]

90. Marafi, M.; Stanislaus, A. Spent catalyst waste management:A review. Part I-Developments in hydroprocessingcatalyst waste reduction and use. Resour. Conserv. Recycl. 2008, 52, 859-873. [CrossRef]

91. Lázaro, M.J.; Gálvez, M.T.; Izquierdo, E.; García-Bordejé, C.; Ruiz, R.; Juan, R.; Moliner, J. Novel carbon-based catalysts for the reduction of NO: Influence of support precursors and active phase loading. Catal. Today 2008, 137, 215-221. [CrossRef]

92. Wu, C.; Liang, Y.; Yang, K.; Min, Y.; Liang, Z.; Zhang, L.; Zhang, Y. Clickable periodic mesoporous organosilica monolith for highly efficient capillary chromatographic separation. Anal. Chem. 2016, 88, 1521-1525. [CrossRef] [PubMed]

93. Hu, P.; Long, M.; Bai, X.; Wang, C.; Cai, C.; Fu, J. Monolithic cobalt-doped carbon aerogel for efficient catalytic activation of peroxymonosulfate in water. J. Hazard. Mater. 2017, 332, 195-204. [CrossRef] [PubMed]

94. Zhan, S.; Zhang, H.; Zhang, Y.; Shi, Q.; Li, Y.; Li, X.J. Efficient $\mathrm{NH}_{3}$-SCR removal of NOx with highly ordered mesoporous $\mathrm{WO}_{3}(\mathrm{X})-\mathrm{CeO}_{2}$ at low temperatures. Appl. Catal. B Environ. 2017, 203, 199-209. [CrossRef] [PubMed]

95. Rodriguez-reinoso, F. The role of carbon materials in heterogeneouscatalysis. Carbon 1998, 36, 159-175. [CrossRef]

96. Thiruvenkatachari, R.; $\mathrm{Su}$, S.; An, H.; Yu, X.X. Post combustion $\mathrm{CO}_{2}$ capture by carbon fibremonolithic adsorbents. Prog. Energ. Combust. Sci. 2009, 35, 438-455. [CrossRef]

97. Dey, S.; Dhal, G.C. Deactivation and regeneration of Hopcalitecatalyst for carbon monoxide oxidation: A review. Mater. Today Chem. 2019, 14, 100180. [CrossRef]

98. Zhou, X.; Yi, H.; Tang, X.; Deng, H.; Liu, H. Thermodynamics for the adsorption of $\mathrm{SO}_{2}, \mathrm{NO}$ and $\mathrm{CO}_{2}$ from flue gas on activated carbon fiber. Chem. Eng. J. 2012, 200-202, 399-404. [CrossRef]

99. Sircar, S.; Myers, A.L. Gas adsorption operations: Equilibrium, kinetics, column dynamics and design. Adsorpt. Sci. Technol. 1985, 2, 69-87. [CrossRef]

100. Dabrowski, A. Adsorption from theory to practice. Adv. Colloid Interface Sci. 2001, 93, 135-224. [CrossRef]

101. Singh, V.K.; Kumar, E.A. Comparative studies on $\mathrm{CO}_{2}$ adsorption kinetics by solid adsorbents. Energ. Procedia 2015, 90, 316-325. [CrossRef]

102. Rezaei, F.; Webley, P. Structured adsorbents in gas separation processes. Sep. Purif. Technol. 2010, 70, $243-256$. [CrossRef]

103. Podkościelny, P.; Nieszporek, K. Adsorption of phenols from aqueous solutions: Equilibria, calorimetry and kinetics of adsorption. J. Colloid Interface Sci. 2011, 354, 282-291. [CrossRef] [PubMed] 
104. Park, K.H.; Balathanigaimani, M.S.; Shim, W.G.; Lee, J.W.; Moon, H. Adsorption characteristics of phenol on novel corn grain-based activated carbons. Microp. Mesop. Mater. 2010, 127, 1-8. [CrossRef]

105. Kalavathy, H.; Regupathi, M.I.; Pillai, M.G.; Miranda, L.R. Modelling, analysis and optimization of adsorption parameters for $\mathrm{H}_{3} \mathrm{PO}_{4}$ activated rubber wood sawdust using response surface methodology (RSM). Colloids Surf. B Biointerfaces 2009, 70, 35-45. [CrossRef]

106. Chaudhary, N.; Balomajumder, C. Optimization study of adsorption parameters for removal of phenol on aluminum impregnated fly ash using response surface methodology. J. Taiwan Inst. Chem. Eng. 2014, 45, 852-859. [CrossRef]

107. Thommes, M.; Kaneko, K.; Neimark, A.V.; Olivier, P.; Rodriguez-Reinoso, F.; Rouquerol, J.; Kenneth, S.W. Physisorption of gases, with special reference to the evaluation of surface area and pore size distribution (IUPAC technical report). Pure Appl. Chem. 2015, 87, 1-19. [CrossRef]

108. Ravennia, G.; Elhamib, O.H.; Ahrenfeldta, J.; Henriksena, U.B.; Neubauerb, Y. Adsorption and decomposition of tar model compounds over the surface of gasification char and active carbon within the temperature range 250-800 ․ C. Appl. Energ. 2019, 241, 139-151. [CrossRef]

109. Sumathi, S.; Bhatia, S.; Lee, K.T.; Mohamed, A.R. Performance of shell activated carbon impregnated with $\mathrm{CeO}_{2}$ and $\mathrm{V}_{2} \mathrm{O}_{5}$ catalyst in simultaneous removal of $\mathrm{SO}_{2}$ and NO. J. Appl. Sci. 2010, 12, 1052-1059.

110. Sircar, S. Comments on practical use of Langmuir gas adsorption isotherm model. Adsorption 2017, 23, 121-130. [CrossRef]

111. Ghorbani, F.; Younesi, H.; Ghasempouri, S.M.; Zinatizadeh, A.A.; Amini, M.; Daneshi, A. Application of response surface methodology for optimization of cadmium biosorption in an aqueous solution by Saccharomyces Cerevisiae. Chem. Eng. J. 2008, 145, 267-275. [CrossRef]

112. Abdedayem, A.; Guiza, M.; Ouederni, A. Copper supported on porous activated carbon obtained by wetness impregnation: Effect of preparation conditions on the ozonation catalyst's characteristics. C. R. Chim. 2015, 18, 100-109. [CrossRef]

113. Boger, T.; Heibel, A.K. Heat transfer in conductive monolith structures. Chem. Eng. Sci. 2005, 60, $1823-1835$. [CrossRef]

114. Lua, A.C.; Guo, J. Adsorption of sulfur dioxide on activated carbon from oil-palm waste. J. Environ. Eng. 2001, 127, 895-901. [CrossRef]

115. Andrigo, P.; Bagatin, R.; Pagani, G.; Hugo, A. Fixed bed reactors. Catal. Today 2011, 52, 197-221. [CrossRef]

116. Yavuz, R. Sulfur dioxide adsorption by activated carbons having different textural and chemical properties. Fuel 2008, 87, 3207-3215.

117. Gu, T.; Balakotaiah, V. Impact of heat and mass dispersion and thermal effects on the scale-up of monolith reactors. Chem. Eng. J. 2016, 284, 513-535. [CrossRef]

118. Visconti, C.G.; Groppi, G.; Tronconi, E. Accurate prediction of the effective radial conductivity of highly conductive honeycomb monoliths with square channels. Chem. Eng. J. 2013, 223, 224-230. [CrossRef]

119. Groppi, G.; Tronconi, E. Honeycomb supports with high thermal conductivity for gas/solid chemical processes. Catal. Today 2005, 105, 297-304. [CrossRef]

120. Tronconi, E.; Groppi, G.; Visconti, C.G. Structured catalysts for non-adiabatic applications. Curr. Opin. Chem. Eng. 2014, 5, 55-67. [CrossRef]

121. Groppi, G.; Tronconi, E.; Cortelli, C.; Leanza, R. Conductive monolithic catalysts: Development and industrial pilot tests for the oxidation of O-xylene to phthalic anhydride. Ind. Eng. Chem. Res. 2012, 51, 7590-7596. [CrossRef]

122. Yashnik, S.A.; Ismagilov, Z.R.; Koptyug, I.V.; Andrievskaya, I.P. Formation of textural and mechanical properties of extruded ceramic honeycomb monoliths: An ${ }^{1} \mathrm{H}-\mathrm{NMR}$ imaging study. Catal. Today 2005, 105, 507-515. [CrossRef]

123. Liu, Y.X.; Ziyang, L.; Yan, W.; Yanshan, Y.; Jian, F.P.; Jun, Z.; Qian, W. Simultaneous absorption of $\mathrm{SO}_{2}$ and $\mathrm{NO}$ from flue gas using ultrasound/ $\mathrm{Fe}^{2+} /$ heat coactivated persulfate system. J. Hazard. Mater. 2018, 342, 326-334. [CrossRef] [PubMed]

124. Sun, Y.; Zwolińska, E.; Chmielewski, A.G. Abatement technologies for high concentrations of $\mathrm{NOx}$ and $\mathrm{SO}_{2}$ removal from exhaust gases: A review. Crit. Rev. Environ. Sci. Technol. 2016, 46, 119-142. [CrossRef]

125. Jing, W.; Hou, Y.; Guo, Q.; Huang, Z.; Han, X.; Ma, G. Using vanadyl sulfate to prepare carbon-supported vanadium catalyst for flue gas desulfurization. J. Fuel Chem. Technol. 2013, 41, 1223-1233. [CrossRef] 
126. Pan, P.; Chen, H.; Liang, Z.; Zhao, Q. Deposition and corrosion characteristics of liquid-solid droplets on tubular corrosion probes in desulfurized flue gas. Eng. Fail. Anal. 2018, 90, 129-140. [CrossRef]

127. Gingerich, D.B.; Grol, E.; Mauter, M.S. Fundamental challenges and engineering opportunities in flue gas desulfurization wastewater treatment at coal fired power. Environ. Sci. Water Res. Technol. 2018, 4, 909-925. [CrossRef]

128. Liu, X.; Khinast, J.G.; Glasser, B.J. A parametric investigation of impregnation and drying of supported catalysts. Chem. Eng. Sci. 2008, 63, 4517-4530. [CrossRef]

129. Yang, Y.; Chiang, K.; Burke, N. Porous carbon-supported catalysts for energy and environmental applications: A short review. Catal. Today 2011, 178, 197-205. [CrossRef]

130. Skalska, K.; Miller, J.S.; Ledakowicz, S. Trends in NOx abatement: A review. Sci. Total Environ. 2010, 408, 3976-3989. [CrossRef]

131. Nova, I.; Beretta, A.; Groppi, G.; Lietti, L.; Tronconi, E.; Forzatti, P. Monolithic catalysts for NOx removal from stationary sources. Struct. Catal. React. 2005, 171-214.

132. Liu, Q.; Liu, Z. Carbon supported vanadiafor multi-pollutants removal from flue gas. Fuel 2013, 108, $149-158$. [CrossRef]

133. Kasaoka, S.; Sasaoka, E.; Iwasaki, H. Vanadium oxides $\left(\mathrm{V}_{2} \mathrm{Ox}\right)$ catalysts for dry-type and simultaneous removal of sulfur oxides and nitrogen oxides with ammonia at low temperature. Bull. Chem. Soc. Jpn. 1989, 62, 1226-1232. [CrossRef]

134. Athappan, A.; Sattler, M.L.; Sethupathi, S. Selective catalytic reduction of nitric oxide over cerium-doped activated carbons. J. Environ. Chem. Eng. 2005, 3, 2502-2513. [CrossRef]

135. Wang, C.; Feng, Y.; Mingyuan, Z.Y.; Jianming, D.; Jinli, Z.; Peng, C.; Bin, D. Micro spherical $\mathrm{MnO}_{2}-\mathrm{CeO}_{2}-\mathrm{Al}_{2} \mathrm{O}_{3}$ mixed oxide for monolithic honeycomb catalyst and application in selective catalytic reduction of NOx with $\mathrm{NH}_{3}$ at $50-150{ }^{\circ} \mathrm{C}$. Chem. Eng. J. 2018, 346, 182-192. [CrossRef]

136. Abdullah, A.H.; Mat, R.; Somderam, S.; Aziz, A.S.A.; Mohamed, A. Hydrogen sulfide adsorption by zinc oxide-impregnated zeolite (synthesized from Malaysian Kaolin) for biogas desulfurization. J. Ind. Eng. Chem. 2018, 65, 334-342. [CrossRef]

137. Hao, R.; Yaoyu, Z.; Zhaoyue, W.; Yuanpeng, L.; Bo, Y.; Xingzhou, M.; Yi, Z. An advanced wet method for simultaneous removal of $\mathrm{SO}_{2}$ and $\mathrm{NO}$ from coal-fired flue gas by utilizing a complex absorbent. Chem. Eng. J. 2017, 307, 562-571. [CrossRef]

138. Yang, B.; Chen, L.; Sun, F. Recovery of sulfur dioxide from gas mixture in packed bed column. Int. J. Energ. Environ. 2011, 2, 211-218.

139. Liu, Q.; $\mathrm{Liu}, \mathrm{Z}$.; Wu, W. Effect of $\mathrm{V}_{2} \mathrm{O}_{5}$ additive on simultaneous $\mathrm{SO}_{2}$ and $\mathrm{NO}$ removal from flue gas over a monolithic cordierite-based $\mathrm{CuO} / \mathrm{Al}_{2} \mathrm{O}_{3}$ catalyst. J. Fuel Chem. Technol. 2009, 35, 285-289.

140. Salvador, F.; Martin-Sanchez, N.; Sanchez-Hernandez, R.; Sanchez-Montero, M.J.; Izquierdo, C. Regeneration of carbonaceous adsorbents. Part II: Chemical, microbiological and vacuum regeneration. Microp. Mesopor. Mater. 2015, 202, 277-296. [CrossRef]

141. Piotrowski, K.; Wiltowski, T.; Szyma, T.; Mondal, K. Cycling effects on the methane regeneration kinetics of $\mathrm{CuO} / \mathrm{Al}_{2} \mathrm{O}_{3}$ sorbent. Chem. Eng. J. 2005, 108, 227-237. [CrossRef]

142. Jia, Z.; Liu, Z.Y.; Zhao, Y. Kinetics of $\mathrm{SO}_{2}$ removal from flue gas on $\mathrm{CuO} / \mathrm{Al}_{2} \mathrm{O}_{3}$ sorbent catalyst. Chem. Eng. Technol. 2007, 30, 1221-1227. [CrossRef]

143. Edelaar, A.C.S.; Prms, W.; Van, W.P.M. Performance of silica-supported copper oxide sorbents for $\mathrm{SO}_{2} / \mathrm{NO}$ Removal from flue gas II. Selective catalytic reduction of nitric oxide by ammonia. App. Catal. B Environ. 1992, 1, 41-60.

144. Mathieu, Y.; Tzanis, L.; Soulard, M.; Patarin, J.; Vierling, M.; Molière, M. Adsorption of SOx by oxide materials: A review. Fuel Process. Technol. 2013, 114, 81-100. [CrossRef]

145. Afonso, J.C.; Aranda, D.A.G.; Schmal, M.; Frety, R. Regeneration of a Pt-Sri/ $\mathrm{Al}_{2} \mathrm{O}_{3}$ catalyst: Influence of heating rate, temperature and time of Regeneration. Fuel Process. Technol. 1997, 50, 35-48. [CrossRef]

146. Jia, Y.; Jiang, J.; Sun, K.; Chen, C. Oxidation of formic acid over palladium catalyst supported on activated carbon derived from polyaniline and modified lignosulfonate composite. J. Fuel Chem. Technol. 2017, 45, 100-105. [CrossRef]

147. Schobing, J.; Tschamber, V.; Brilhac, J.F.; Auclaire, A.; Hohl, Y. Simultaneous soot combustion and NOx reduction over a vanadia-based selective catalytic reduction catalyst. C. R. Chim. 2018, 21, 221-231. [CrossRef] 
148. Liu, W.; He, X.; Pang, S.; Zhang, Y. Effect of relative humidity on $\mathrm{O}_{3}$ and $\mathrm{NO}_{2}$ oxidation of $\mathrm{SO}_{2}$ on $\alpha-\mathrm{Al}_{2} \mathrm{O}_{3}$ particles. Atmos. Environ. 2017, 167, 245-253. [CrossRef]

149. Shang, X.; Hu, G.; He, C.; Zhao, J.; Zhang, F.; Xu, Y.; Zhang, Y.; Li, J.; Chen, J. Regeneration of full-scale commercial honeycomb monolith catalyst $\left(\mathrm{V}_{2} \mathrm{O}_{5}-\mathrm{WO}_{3} / \mathrm{TiO}_{2}\right)$ used in coal-fired power plant. J. Ind. Eng. Chem. 2012, 18, 513-519. [CrossRef]

150. Yu, Y.; Meng, X.; Chen, J.; Yin, L.; Qiu, T.; He, C. Deactivation mechanism and feasible regeneration approaches for the used commercial $\mathrm{NH}_{3}$-SCR catalysts. Environ. Technol. 2016, 37, 828-836. [CrossRef]

151. Federica, R.; Michela, A.; Gargiulo, R.; Paola, A. Kinetic study and breakthrough analysis of the hybrid physical/chemical $\mathrm{CO}_{2}$ adsorption/desorption behavior of a magnetite-based sorbent. Chem. Eng. J. 2019, 372, 526-535.

152. Rodrigues, C.P.; Kraleva, V.; Ehrich, H.; Noronha, F.B. Structured reactors as an alternative to fixed-bed reactors: Influence of catalyst preparation methodology on the partial oxidation of ethanol. Catal. Today 2016, 273, 12-24. [CrossRef]

153. Zafer, S.; Oana, M.; Merve, K.; Louise, O.; Emrah, O. Trade-off between $\mathrm{NO}_{\mathrm{x}}$ storage capacity and sulfur tolerance on $\mathrm{Al}_{2} \mathrm{O}_{3} / \mathrm{ZrO}_{2} / \mathrm{TiO}_{2}$-based DeNO${ }_{x}$ catalysts. Catal. Today 2019, 320, 152-164.

154. Kolb, G.; Hessel, V. Micro-structured reactors for gas phase reactions. Chem. Eng. J. 2004, 98, 1-38. [CrossRef]

155. Lin, H.; Gao, X.; Luo, Z.; Cen, K.; Huang, Z. Removal of NO. Fuel 2004, 83, 1349-1355. [CrossRef]

156. Yeh, J.T.; Demski, R.J.; Strakey, J.P.; Joubert, J.I. Combined $\mathrm{SO}_{2} / \mathrm{NOx}$ removal from flue gas. Environ. Prog. 1985, 4, 223-228. [CrossRef]

157. Warnecke, R. Gasification of biomass: Comparison of fixed bed and fluidized bed gasifier. Biomass Bioenerg. 2000, 18, 489-497. [CrossRef]

(C) 2020 by the authors. Licensee MDPI, Basel, Switzerland. This article is an open access article distributed under the terms and conditions of the Creative Commons Attribution (CC BY) license (http://creativecommons.org/licenses/by/4.0/). 